\title{
Eco-biostratigraphic advances in late Quaternary geochronology and palaeoclimate: the marginal Gulf of Mexico analogue
}

\author{
Assimina ANTONARAKOU ${ }^{1,}$ *, George KONTAKIOTIS ${ }^{1}$, Aristomenis P. KARAGEORGIS ${ }^{2}$, Eva BESIOU ${ }^{1}$, \\ Stergios ZARKOGIANNIS ${ }^{1}$, Hara DRINIA ${ }^{1}$, Graham P. MORTYN ${ }^{3,4}$ and Efthymis TRIPSANAS ${ }^{5}$
}

1 National and Kapodistrian University of Athens, Faculty of Geology and Geoenvironment, School of Earth Sciences, Department of Historical Geology-Paleontology, Panepistimiopolis, Zografou, 15784, Greece.

2 Hellenic Centre for Marine Research, Institute of Oceanography, 46.7 km Athens-Sounio Avenue, 19013 Anavyssos, Greece

3 Universitat Autònoma de Barcelona (UAB), Institute of Environmental Science and Technology (ICTA), Edifici Z Carrer de les Columnes, Bellaterra 08193, Spain

4 Universitat Autònoma de Barcelona (UAB), Faculty of Geography and History, Montalegre, 6, 08001 Barcelona, Spain

5 Hellenic Petroleum Exploration and Production of Hydrocarbons S.A., 4A Gavrias, Marousi, Spain

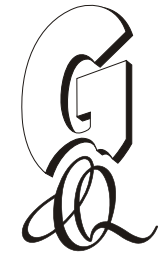

Antonarakou, A., Kontakiotis, G., Karageorgis, A.P., Besiou, E., Zarkogiannis, S., Drinia, H., Mortyn, G.P., Tripsanas, E., 2019. Eco-biostratigraphic advances in late Quaternary geochronology and palaeoclimate: the marginal Gulf of Mexico analogue. Geological Quarterly, 63 (1): 178-191, doi: 10.7306/gq.1457

Associate editor: Wojciech Granoszewski

This study combines high-resolution planktonic foraminiferal eco-biostratigraphy and palaeoclimatic data from the high-sedimentation-rate core JPC-26 from the northwestern margin of the Gulf of Mexico (GoM). The eco-biozones recognized (GOMPFE1-12) being correlated with published Mg/Ca-based sea surface temperatures. This updated palaeoclimatic and stratigraphic reference record facilitates correlations with the Greenland ice core events and their climatic relationships, and also provides a solid stratigraphic framework for correlations with other palaeoclimatic and palaeoceanographic records in the circum-GOM/Caribbean region. This multidisciplinary approach underlines the utility of supporting conventional dating methodologies with different constraints, and further reveals a powerful tool for reliably correlating marine records between comparable deep-sea marginal settings and coeval sequences of this region.

Key words: integrated stratigraphy, Late Glacial-Holocene transition, planktonic foraminiferal eco-bioevents, deep-sea sedimentary correlations, climate variability, palaeoceanography.

\section{INTRODUCTION}

In the last half-century, considerable interest has developed regarding the role of the (sub)tropical oceans in climate change, and in particular, oceanic sub-basins and marginal seas that are often more responsive to palaeoceanographic and palaeoclimatic changes than to broader global ocean basins, because of their smaller size and partial isolation (Marino et al., 2009; Kontakiotis et al., 2013; Kontakiotis, 2016). As an example, the tropical Western Hemisphere Warm Pool (WHWP), which encompasses the Caribbean Sea and the Gulf of Mexico (GoM), is an important heat and moisture source for climate in the

\footnotetext{
* Corresponding author, e-mail: aantonar@geol.uoa.gr
}

Received: November 2, 2018; accepted: January 31, 2019; first published online: April 1, 2019
North Atlantic region (Wang and Enfield, 2001), and therefore acts as a key regulator of subpolar North Atlantic oceanography and climate in Europe. In particular, the GoM is a key area for global thermohaline circulation (THC), global heat exchange and climate system (Broecker, 1991), because its hydrographic characteristics (high sea surface temperature (SST) and salinity (SSS) values) partly control Gulf Stream physical properties. Its small volume, compared with major ocean basins, causes changes in its climatic forcing to be recorded virtually instantaneously in palaeoceanographic proxy data such as stable isotopes, geochemical ratios, and microfossil abundances. Moreover, the direct influence of North Atlantic surface water on the faunal assemblages gives a measure of the close hydrological relationship between the North Atlantic and the GoM water masses, and underlines the prominent role of the GoM in the understanding of global climatic evolution (Thirumalai et al., 2018).

Due to its latitudinal position, the semi-enclosed character, the high sedimentation rates and close atmospheric and oce- 
anic connections with the North Atlantic region, the GoM is among the most studied marginal basins. In particular, the interplay between Mississippi River discharge, the open ocean water masses and atmospheric circulation creates a complex and dynamic system responsible for hydrological fluctuations on both annual and long-term timescales. To better understand the impact of these parameters on the regional climate, a number of studies based on various marine proxies has focused on the hydrologic evolution of the basin during the late Quaternary (Metcalfe et al., 2000; Aharon, 2003, 2006; Poore et al., 2003; Flower et al., 2004; LoDico et al., 2006; Nürnberg et al., 2008; Ziegler et al., 2008; Richey et al., 2011, 2012; Spear et al. 2011a; Rasmussen and Thomsen, 2012; Limoges et al., 2014; del Monte-Luna et al., 2015; Antonarakou et al., 2015; Shakun et al., 2016; Reynolds et al., 2018). However, the reconstruction of the variability of late Quaternary climate needs detailed eco-litho-chronostratigraphic control (Triantaphyllou et al. 2009; Siani et al., 2010; Drinia et al., 2016; Koutrouli et al., 2018). In this respect, notable contributions are required from micropaleontological, biogeochemical, and sedimentological studies. In particular, morphological and compositional changes in the planktonic foraminiferal assemblages recorded in marine sediments and/or the water column provide detailed information on the physical and chemical properties of the surrounding water masses and their relationships with climatic variability (Renaud and Schmidt, 2003; Schmidt et al., 2004a, b; Spear et al., 2011b; Kontakiotis et al., 2011, 2013, 2016a Thirumalai et al., 2014; Antonarakou et al., 2015; Jonkers et al., 2015; Kontakiotis, 2016; Arellano-Torres and Machain-Castillo, 2017; Reynolds et al., 2018; Wilson et al., 2018). For instance, it has been suggested that planktonic foraminifera alter their shape and size, which determine their weight and their overall density in direct response to changes in water density and viscosity to retain or modify their hydrodynamic behaviour accordingly (Caromel et al., 2014; Zarkogiannis et al., 2019a, b). Understanding the drivers of these changes, along with the implications for changes in biogeochemistry and climate, is key to understanding the past hydroclimate. They also allow the definition of a detailed sequence of regional eco-bioevents for the late Quaternary (e.g., temporary appearance or disappearance, or significant relative abundance variations of specific taxa; Wilson, 2012), reflecting climatic oscillations, that represent an important tool for accurate subdivision of the late Quaternary stratigraphic record and facilitate correlations between sites in the different sub-basins. The presence of distinct temporal Quaternary organic-rich zones (ORZ; Tripsanas et al., 2013) in GoM successions represents an additional, independent tool for dating and correlating marine sedimentary archives. They provide isochronous marker horizons that can be correlated via geochemical fingerprinting with well-dated meltwater flooding events (Tripsanas et al., 2007; Meckler et al., 2008; Sionneau et al., 2008; Montero-Serrano et al., 2009; Sionneau et al., 2010; Vetter et al., 2017).

In this work we refine and extend previous biostratigraphic schemes for the area investigated (Kennett and Huddlestun, 1972; Kennett et al., 1985; Flower and Kennett, 1990; Martin et al., 1990) and further highlight the stratigraphic relationship between foraminiferal and climatic events since the late glacial period. We report a high-resolution planktonic foraminiferal quantitative distribution pattern, and further correlate the ecobioevents recognized with $\mathrm{Mg} / \mathrm{Ca}$-based SST results (Antonarakou et al., 2015). As a result, this updated and comprehensive reconstruction can be considered as a useful palaeoclimatic and stratigraphic reference record, facilitating correlations with the Greenland ice core events and their climatic relationships, and also providing a solid stratigraphic framework for correlations with other palaeoclimatic and palaeoceanographic records in the circum-GoM/Caribbean region.

\section{OCEANOGRAPHIC SETTING}

The GoM is a semi-enclosed oceanic basin on the southeastern margin of North America that covers an area of $1,555,000 \mathrm{~km}^{2}$ (Fig. 1). It is connected to the Atlantic Ocean by the Florida Strait (FS) and to the Caribbean Sea by the Yucatan Channel (YC; INEGI, 2014). Its hydrographic properties result mainly from the interplay between the open ocean water masses, Mississippi River discharge, and atmospheric circulation. The surface circulation in the GoM is known to be a key element in the North Atlantic and the Atlantic Meridional Overturning Circulation (AMOC), as it conveys heat and salt from low to high latitudes via the Gulf Stream; it is largely influenced by: (1) the energetic Loop Current (LC) and its associated eddy field (Ohlmann et al., 2001; Morey et al., 2003b; Liu et al., 2012; Gopalakrishnan et al., 2013; Schmitz et al., 2013; Weisberg and Liu, 2017) in the eastern part, and (2) a less prominent west-flowing anticyclonic gyre that moves on to the western part of the basin, varying appreciably in intensity with season and location (Behringer et al., 1977; Müller-Karger et al., 1991; Zavala-Hidalgo et al., 2006; Putrasahan et al., 2017). The most prominent surface circulation feature in the GoM, the LC, brings warm and salty tropical waters originating from the Caribbean Sea through the YC into the GoM, loops northwest, and exits into the North Atlantic Ocean through the Florida Straits (Florida Current - FC), and eventually feeds the Gulf Stream (GS; Fig. 1; Elliott, 1982; Blumberg and Mellor, 1985; Hofmann and Worley, 1986; Jochens and DiMarco, 2008; Auladell et al., 2010; Oey et al., 2013). The latitudinal extension of the Caribbean water inflow (Caribbean Current, CC) into the basin is seasonally modulated by changes in the position of the Intertropical Convergence Zone (ITCZ; Poore et al., 2004, 2005; Nürnberg et al., 2008; Ziegler et al., 2008). Northward migration of the ITCZ during the boreal summer causes the LC to propagate farther north, influencing the hydrological properties of the entire basin (temperature, salinity, wind direction), and finally creates drier conditions during the boreal winter and rainy conditions during the boreal summer (Saha, 2010). Apart from the distinct role of the LC, fluvial freshwater discharge (mainly the Mississippi River system) directly affected by the prevailing precipitation patterns and climatic conditions (Montero-Serrano et al., 2010, 2011) also influences the GoM surface hydrography, by modifying the SSS, and by impacting to some extent the thermocline circulation via the GS (Aharon, 2003; Morey et al., 2003a; Flower et al., 2004). Moreover, the large seasonal loadings of freshwater, inorganic and organic matter, and nutrients maintain the northern GoM as an active ecosystem with dynamic physical and biogeochemical processes, such as interactions of eddy cyclone-anticyclone pairs with the water column, bottom topography, increased offshore productivity, and advection of shelf material into the central Gulf (Biggs and Müller-Karger, 1994; Toner et al., 2003; Wawrik et al., 2003; Corbett et al., 2004; Luo et al., 2016; Chen and Hu, 2017). In the modern climate system, GoM mean annual SST is $\sim 25.85^{\circ} \mathrm{C}$ with large seasonal amplitude $\left(\sim 8.5^{\circ} \mathrm{C}\right)$, whereas salinity varies from about 34.4 to 36.3 psu (Antonov et al., 2010; Locarnini et al., 2010). 


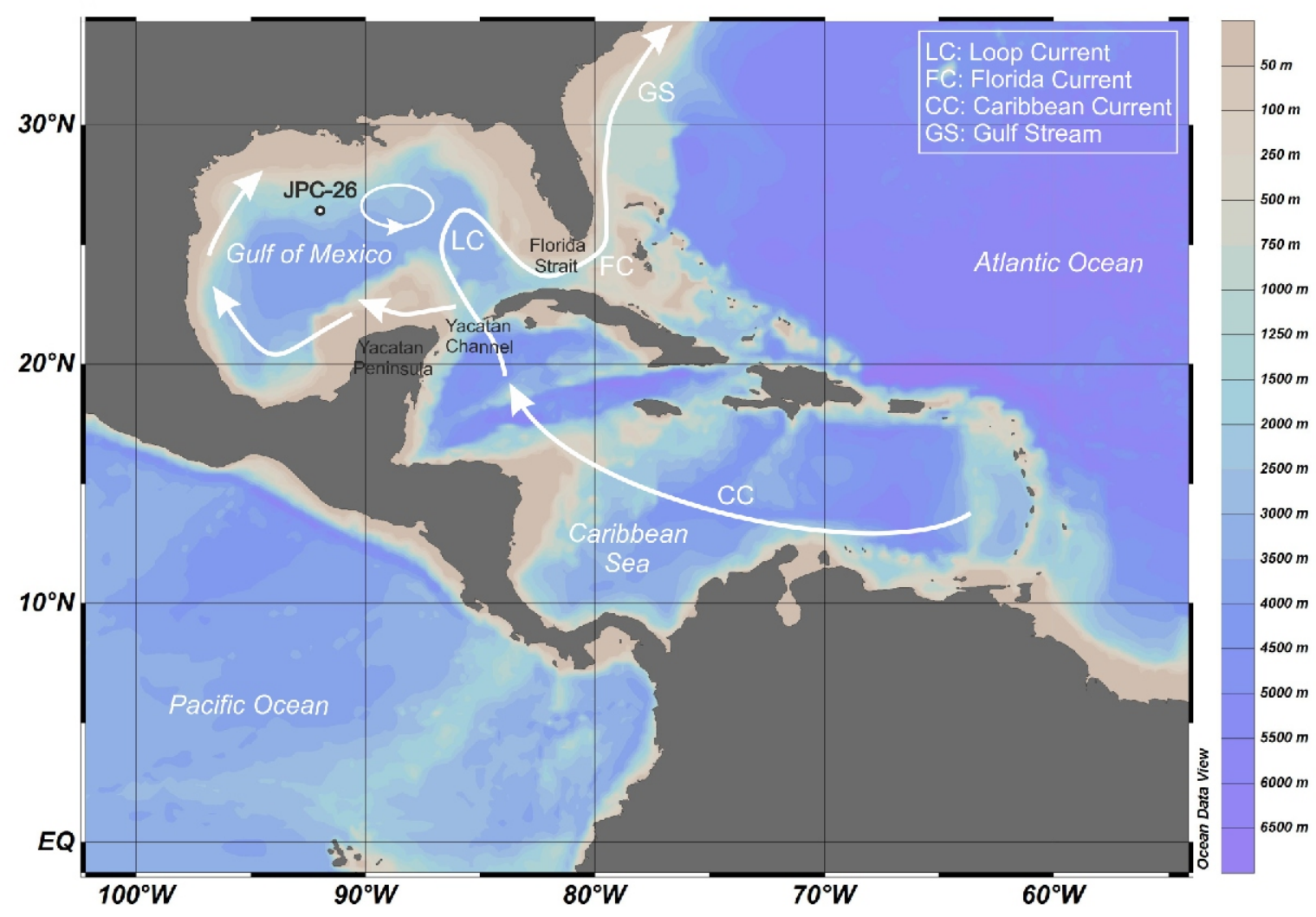

Fig. 1. Bathymetric map of the Gulf of Mexico (GoM) showing the core location and the main patterns of the surface circulation (white arrows, solid circles)

The top-right inset shows the names of the main currents, as described in the text

\section{MATERIAL AND METHODS}

CORE SELECTION

Core JPC-26 (1995 m b.s.I.) was recovered from the northwestern continental slope of the GoM $\left(26^{\circ} 22.44^{\prime} \mathrm{N}\right.$, $92^{\circ} 01.62^{\prime} \mathrm{W}$ ) at a depth of $1995 \mathrm{~m}$ (Fig. 1), during the R/V Knorr 1998 cruise, using the Woods Hole Oceanographic Institution jumbo piston corer. The core is located offshore of the former mouth of the Mississippi River within the Bryant Canyon area, which is represented by a network of intraslope basins separated from each other by sills/plateaus (Tripsanas et al., 2007). The upper $3 \mathrm{~m}$ of the core analysed represents an uninterrupted last glacial to Holocene interval, including the Last Glacial Maximum (LGM) event, and the last glacial termination period (T1). This core is also characterized by a Holocene thickness of $1.5 \mathrm{~m}$ that can offer a time resolution on the order of a few hundred years per sample step. The Late Quaternary provides the best time interval for this research because sea level history is well constrained temporally; moreover, centennial to millennial scale chronostratigraphic resolution is highly achievable through planktonic bio-ecozonation, while palaeoclimate history is best constrained through previously integrated sedimentological, micropalaeontological, stratigraphic and palaeoclimatic studies (Poore et al., 2003; LoDico et al., 2006; Montero-Serrano et al., 2009, 2010; Williams et al., 2010; Rasmussen and Thomsen, 2012; Tripsanas et al., 2013; Limoges et al., 2014; Antonarakou et al., 2015; Arellano-Torres and Machain-Castillo, 2017).

\section{LITHO-CHRONOSTRATIGRAPHY OF MARINE SEDIMENT CORE JPC-26}

The sedimentary record of the uppermost $3 \mathrm{~m}$ of JPC-26 was sampled at $2-5 \mathrm{~cm}$ intervals, and consists of three distinct lithostratigraphic units (I-III). The upper unit I (0-1.52 m) consists of reddish-brown to pale yellow hemipelagic mud, and the sporadic presence of manganese-rich, dark brown mud horizons ( $3 \mathrm{~cm}$ thick; in intervals $0.10-0.32 \mathrm{~m}$ and $0.45-0.60 \mathrm{~m})$. In unit II (1.52-1.90 m), hemipelagic muds were intercalated with three organic-rich zones $\left(0.60-0.95 \% \mathrm{C}_{\text {org }}\right.$ ) slightly (ORZ I) or intensely (ORZ II, III) bioturbated (Tripsanas et al., 2007). Their downcore transition to pale greenish-grey hemipelagic muds of unit III $(1.90-3 \mathrm{~m})$ is characterized by the presence of two organic-rich $\left(0.75-1.30 \% C_{\text {org }}\right)$ reddish-brown (RT) and dark green (GT) mud turbidites. The chronostratigraphy of JPC-26 is based on eight accelerator mass spectrometry radiocarbon $\left(\mathrm{AMS}{ }^{14} \mathrm{C}\right.$ ) dates, supplemented by additional tie-points derived from the determination of both the isotopic and faunal profile (Antonarakou et al., 2015).

\section{MICROPALAEONTOLOGICAL ANALYSES}

For detailed quantitative micropalaeontological analysis, we picked specimens of planktonic foraminifera from about $15 \mathrm{~g}$ of dry marine sediment, taken every $2-5 \mathrm{~cm}$ along the core. All the sediment samples were washed with running water through a $63 \mu \mathrm{m}$ sieve. After washing and drying at $50^{\circ} \mathrm{C}$, the samples were sieved and the $>125 \mu \mathrm{m}$ size fraction was split with an Otto micro-splitter into aliquots, from which at least 300 specimens 


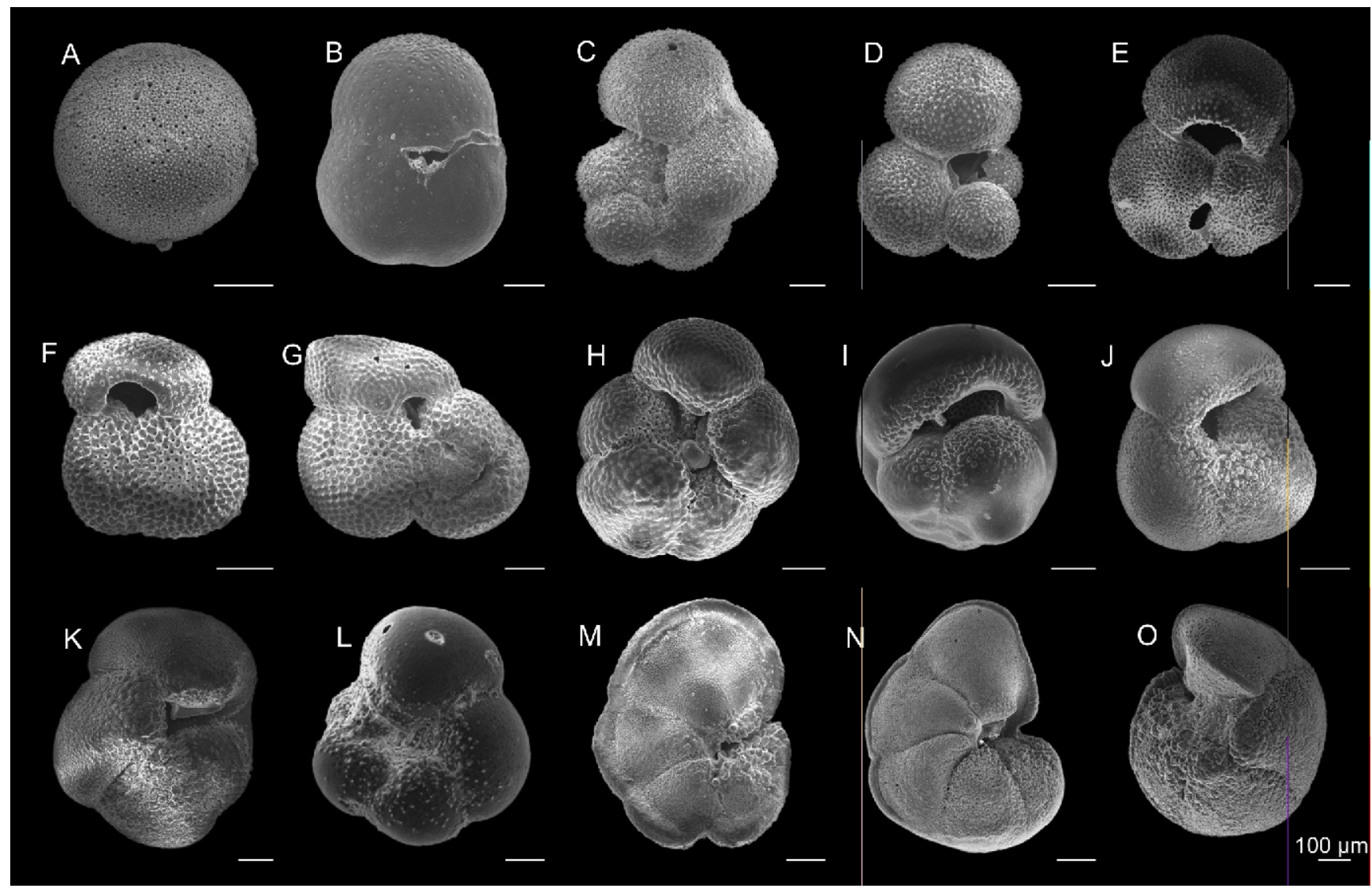

Fig. 2. High-resolution SEM photomicrographs of the planktonic foraminiferal species most indicative for the present study in core JPC-26

A - Orbulina universa; B - Sphaeroidinella dehiscens; C - Globogerinella aequilateralis; D - Globigerina bulloides; E - Globigerinoides ruber sensu stricto; F - Globigerinoides ruber sensu lato; G - Globigerinoides sacculifer; H - Neogloboquadrina dutertrei; I - Pulleniatina obliquiloculata; J - Globorotalia inflata; K - Globorotalia crassaformis; L - Globorotalia scitula; M - Globorotalia menardii; N - Globorotalia tumida; $\mathbf{O}$ - Globorotalia truncatulinoides

of planktonic foraminifera were picked, identified and counted using morphospecies-specific and/or specialized taxonomic references (Kennett and Srinivasan, 1983; Hemleben et al., 1989; Kontakiotis et al., 2017). The number of planktonic foraminifera counted is statistically reliable for both ecobiostratigraphic and palaeoclimatic reconstructions (Patterson and Fishbein, 1989; Capotondi et al., 1999; Drinia and Antonarakou, 2003; Sprovieri et al., 2003; Sbaffi et al., 2004; Budillon et al., 2009; Triantaphyllou et al., 2009; Siani et al., 2010; Drinia et al., 2016; Bonfardeci et al., 2018). All the specimens identified showed very good levels of preservation, with no traces of dissolution or damage found in the tests. Raw data were transformed into percentages of the total abundance and relative percentage abundance curves were plotted, after exclusion of rare species $(<3 \%$; Globigerinoides conglobatus, Globigerinella calida, Globigerinoides tenellus, Hastigerina pelagica, Globorotalia ungulata) and grouping of species with phylogenetic affinities and similar ecological characteristics (e.g., Globigerina bulloides and Globigerina falconensis were grouped in G. bulloides gr., Globigerinoides trilobus and Globigerinoides sacculifer in G. sacculifer gr., Globigerinella aequilateralis and Globigerinella calida in the G. aequilateralis gr., Globorotalia menardii and Globorotalia tumida in G. menardii gr., and Neogloboquadrina pachyderma and Neogloboquadrina dutertrei in neogloboquadrinids respectively). The planktonic foraminiferal relative distributions are also used as a first-order estimate of SST variations. An index of the SST variations was constructed based on the down-core variation of planktonic foraminiferal abundances, and it was referred to as the Planktonic Palaeoclimatic Curve (PPC). The PPC was obtained by the formula $(w-c) \times 100 /(w+c)$, where: $w$ represents the warm-water indicators and $c$ the cold water indicators (Rohling et al., 1993; Kontakiotis, 2016). For palaeoclimatic interpretation, the PPC record was further compared with previously published SST proxy data $\left(\delta^{18} \mathrm{O}, \mathrm{Mg} / \mathrm{Ca}\right)$ from the same or nearby cores (Flower et al., 2004; Ziegler et al., 2008; Williams et al., 2010; Rasmussen and Thomsen, 2012; Schmidt et al., 2012; Tripsanas et al., 2013; Antonarakou et al., 2015; Arellano-Torres and Machain-Castillo, 2017).

\section{RESULTS}

\section{SEDIMENTATION RATES}

Within the GoM, Bryant Canyon is exceptional in that rapid sedimentation sustained by high rates of terrigenous sediment delivery and surface marine productivity makes this basin an excellent recorder of palaeoenvironmental and palaeoclimatic conditions. Sedimentation in the basin is mainly hemipelagic and is strongly linked to the Mississippi River detrital supply (Bouma et al., 1985). This type of deposition is due to the rise of sea level that led to the confinement of river-sourced sediments to the continental shelf, and the prevalence of hemipelagic sedi- 
mentation over the continental slope of the northwestern GoM. The sediment record here investigated spans the interval from the LGM and the subsequent transition (T1) into the late Holocene (i.e. 0-21 ka; Antonarakou et al., 2015) with an average sedimentation rate $(\mathrm{SR})$ of $13.5 \mathrm{~cm} / \mathrm{ky}$, which is in agreement with prior studies (Leventer et al., 1983; Aharon, 2003; Poore et al., 2003; LoDico et al., 2006; Tripsanas et al., 2007). Sedimentation rates of each unit reveal a strong down-core increasing trend, with the higher SR occurring during the glacial section (unit III; $18.18 \mathrm{~cm} / \mathrm{ky}$ ) and the deglacial meltwater pulses (unit II; $13.29 \mathrm{~cm} / \mathrm{ky}$ ). Lower SR occurred during the Holocene interval (unit I; $11.44 \mathrm{~cm} / \mathrm{ky}$ ) and is consistent with other observations of reduced sedimentation rates after $13 \mathrm{cal}$ ka BP (Williams and Kohl, 1986; Montero-Serrano et al., 2009).

\section{PLANKTONIC FORAMINIFERAL FAUNAL DISTRIBUTION}

Qualitative analysis of the planktonic foraminifera allows us to identify 24 species lumped into 15 groups: Globigerinoides ruber alba, Globigerinoides ruber rosea, Globigerinoides sacculifer gr., Globigerina bulloides gr., Globogerinella aequilateralis gr., Globorotalia scitula, Globorotalia menardii gr., Orbulina universa, neogloboquadrinids, Globorotalia crassaformis, Globorotalia inflata, Globorotalia truncatulinoides, Pulleniatina obliquiloculata, and Sphaeroidinella dehiscens (Fig. 2). The stratigraphic distribution of the most abundant species and species groups over the last $21 \mathrm{kyr}$ BP is shown in Figure 3. The overall changes in the planktonic foraminiferal abundances from JPC-26 are consistent with previously documented changes in the GoM foraminiferal assemblages related to the transition from glacial to interglacial conditions (e.g., Flower and Kennett, 1995; Poore et al., 2003).

Globigerinoides ruber, G. sacculifer gr., neogloboquadrinids, O. universa, G. crassaformis, G. menardii gr., and $G$. truncatulinoides are the most abundant species. With the exception of the representatives of $G$. menardii gr., that are virtually absent from the base of the succession up to $1.36 \mathrm{~m}$, they have an almost continuous distribution throughout the interval studied. Globigerinoides ruber was the dominant species over the entire duration (33.2\% on average). The white (G. ruber alba) and pink (G. ruber rosea) varieties of this species were counted as separate categories, showing that the white variety is about 15 to $30 \%$ more abundant than the pink variety (Fig. 3). The species G. menardii gr., $P$. obliquiloculata, G. sacculifer gr., and $G$. truncatulinoides display an upward increase in abundance. A sporadic distribution is recorded for G. bulloides and $G$. inflata, since they are significant contributors only in the basal part of the core with an average contribution of $\sim 10-25 \%$. The latter exists in the faunal composition up to $1.40 \mathrm{~m}$ and then completely disappears, while the former, although it does not disappear from the sequence, reduces its populations to $<5 \%$ in the upper half of the core. Globorotalia scitula presents a discontinuous distribution and shows minor abundance peaks and/or intervals of occurrence limited mainly to the middle part of the core. The distribution pattern of neogloboquadrinids is characterized by high percentages in the upper half of the core, with their maximum percentages occurring during the deposition of organic-rich sediments and throughout the Holocene.

\section{PLANKTONIC PALAEOCLIMATIC CURVE}

From the base of the core up to $2.31 \mathrm{~m}$ (19.0 ka), the lowest values of the PPC ( 20-40\%) are indicative of the glacial period (Fig. 4). This interval is characterized by the dominance of cold water indicators, such as G. inflata, G. crassaformis,
G. bulloides and neogloboquadrinids, whereas warm water species are restricted in these faunal assemblages. The palaeoclimatic curve shows relative high variability upcore from 2.31-1.52 m (19.0-13.0 ka), displaying a characteristic pattern corresponding to deglaciation. The warm ( 50-60\%) interval 2.31-1.90 m (19.0-15.8 ka) is followed by a significant cooling, as reflected by the abrupt drop to glacial values $(\sim 20 \%)$. The rises towards more positive values in the PPC correspond to pronounced deglacial warming peaks (MWFs of Aharon, 2003). The brief rebound to slightly lower values around $60 \%$ at $12.5 \mathrm{ka}$ is related to the Greenland Stadial 2 (GS-2)/Younger Dryas (YD) cooling event, and therefore, despite the lower resolution of this part of the core, we can suggest that the transition to the Holocene was not characterized by a gradual warming, but instead was punctuated by the cold YD interval. The Holocene section of the record $(1.36-0 \mathrm{~m})$ is marked by a relatively very warm interval with values close to or greater than $80 \%$. Particularly in the middle Holocene, the PPC values approximate $95 \%$, indicative of the Holocene Climatic Optimum (HCO). PLANKTONIC FORAMINIFERAL ECO-BIOZONATION AND COMPARISON
WITH PREVIOUS ECO-BIOSTRATIGRAPHIC SCHEMES IN THE PERI-CARIBBEAN REGION

The detailed quantitative distribution of planktonic foraminifera resulted in the identification of 12 eco-biozones (GOMPFE 1-GOMPFE 12) spanning approximately the last $21 \mathrm{kyr}$ BP (Fig. 3). Each eco-biozone is defined by using a progressive number from the top to the base of the core and identified by local (re-) occurrences and/or temporary disappearances of the main specific taxa in association with more or less important fluctuations of their abundance, indicative of modification in marine conditions, such as vertical mixing, as well as changes in marine productivity and surface water temperature, salinity and/or current flow.

- GOMPFE 12 (2.96-2.61 m; 21.13-20.41 ka): this is recognized between the base of the succession studied and $2.60 \mathrm{~m}$. In this interval the assemblages are dominated by the cold-water species $G$. inflata and $G$. crassaformis gr. This interval is also marked by a significant contribution of $O$. universa to the planktonic fauna. The base of this eco-biozone falls within the middle part of the biozone Y2 of Kennett et al. (1985).

- GOMPFE 11 (2.61-2.36 m; 20.41-19.01 ka): this zone is bounded by two increases in $G$. crassaformis gr. A near-absence of $G$. inflata, an increase of $G$. ruber (both varieties), the highest abundance of G. bulloides, a strong decrease of $O$. universa, and the presence of $G$. scitula in the lower part are the main features of this interval. This eco-biozone corresponds to the upper part of the biozone Y2 of Kennett et al. (1985).

- GOMPFE 10 (2.36-1.91 m; 19.01-15.89 ka): the lower boundary of this eco-biozone is identified by the sudden decrease in G. ruber rosea, an increase in G. sacculifer, and the last consistent occurrence of $G$. inflata (Kennett et al., 1985, bioevent f8 of Antonarakou et al., 2015). It is mainly characterized by a strong increase in abundance (acme) of G. crassaformis gr., O. universa and G. ruber, and the occurrence of $G$. truncatulinoides, neogloboquadrinids and $G$. aequilateralis which reach abundance values around $10 \%$. This eco-biozone coincides with the uppermost part of the biozone Y2 of Kennett et al. (1985).

- GOMPFE 9 (1.91-1.79 m; 15.89-15.28 ka): this is bounded by two sharp decreases in G. ruber rosea, and 


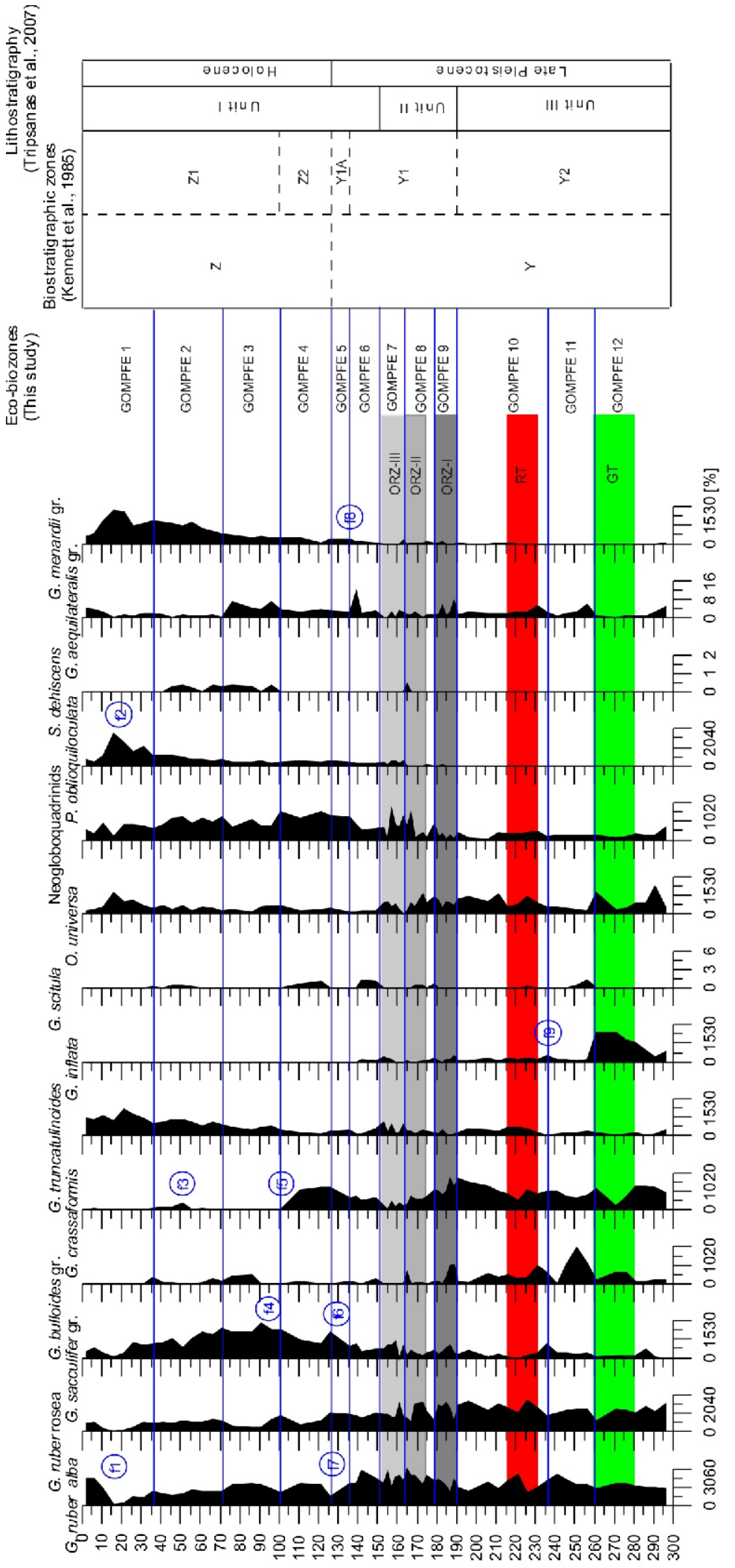

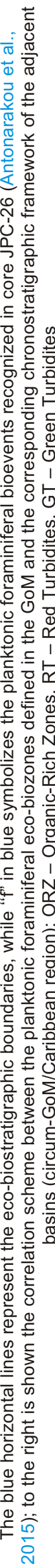

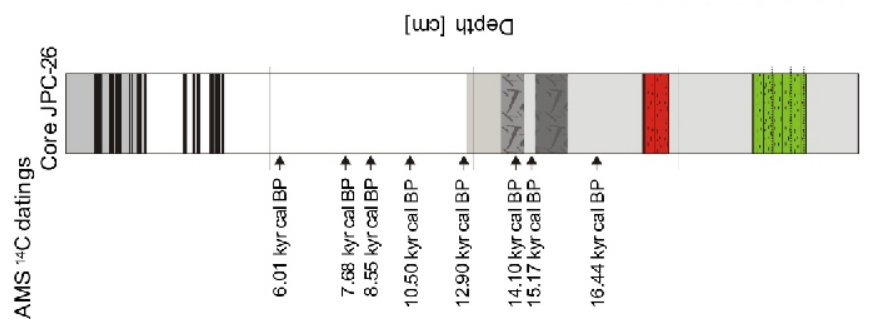




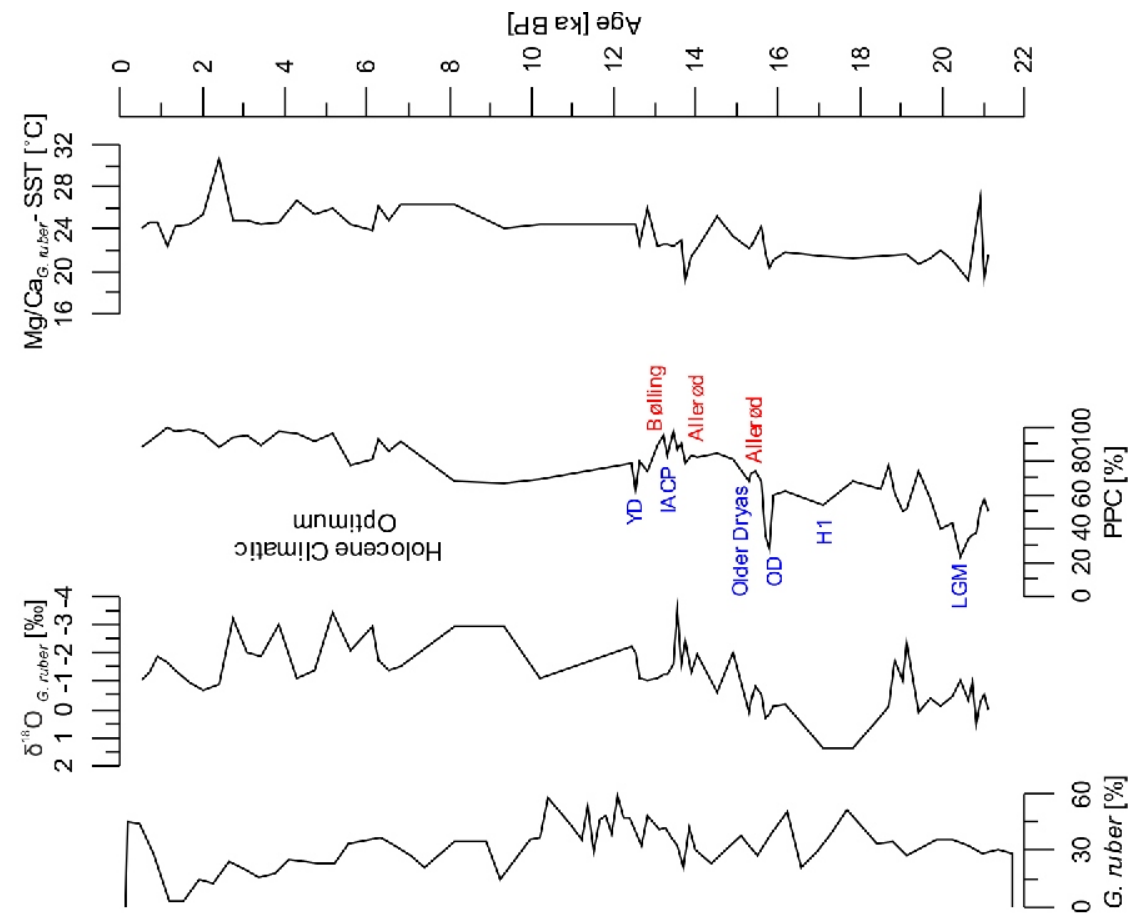

总

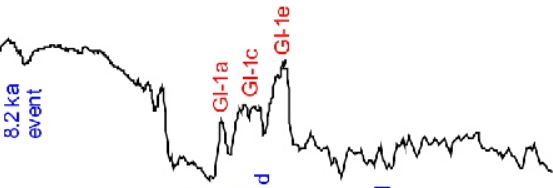

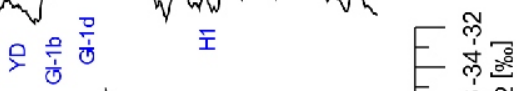

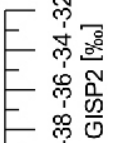

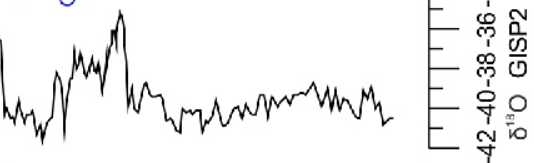

\begin{tabular}{|c|c|c|c|c|c|}
\hline 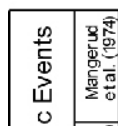 & әиәэо이 & $\rho$ & థో & 8 & 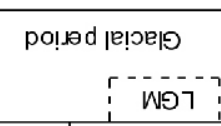 \\
\hline 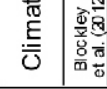 & $\stackrel{\frac{\pi}{N}}{a}$ & $\overline{\dot{\phi}}$ & 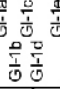 & & 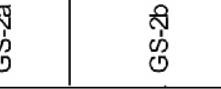 \\
\hline
\end{tabular}

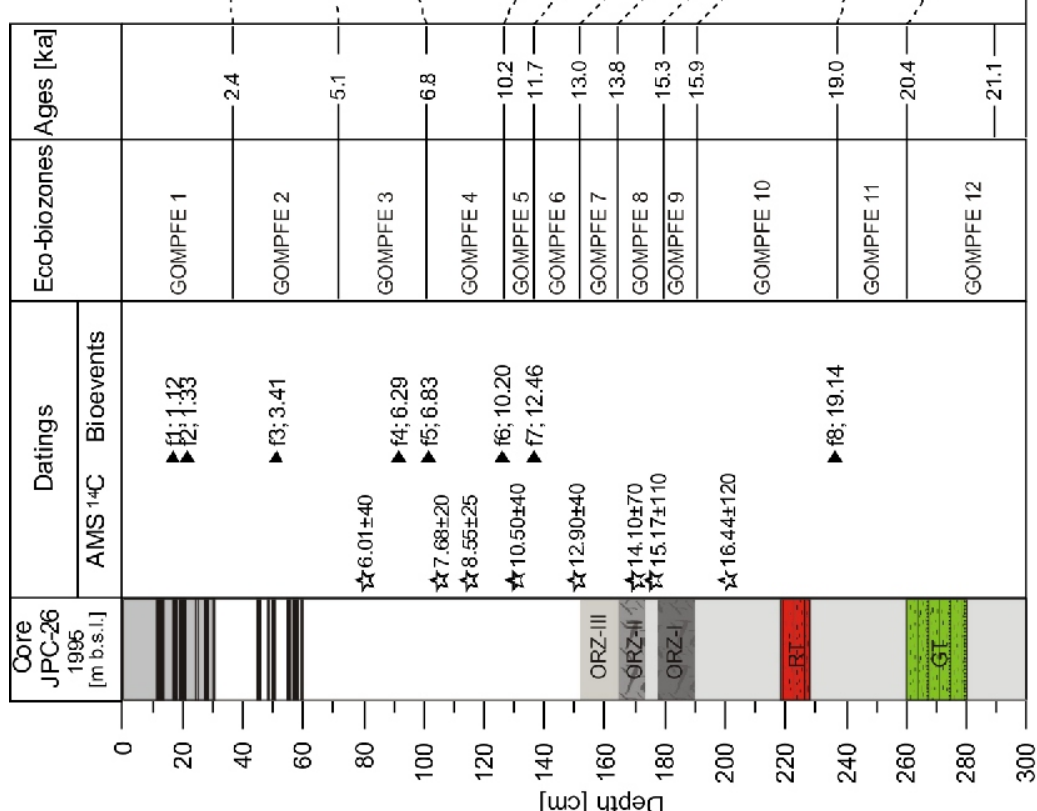

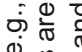

()

웅 $\frac{1}{2}$

D.․․

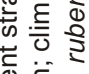

要运

山它

क

类恋

o.

ठ을

용

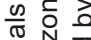

픈 응 $\frac{1}{\pi}$

过

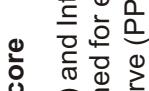

ง

응

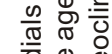

क्ष

की

政

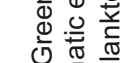

응

o 0

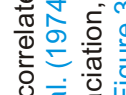

$\frac{\pi}{4} \frac{\pi}{0} \frac{\pi}{2}=$

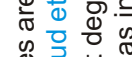

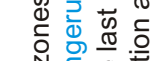

응 뜬

定

응

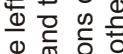

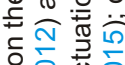

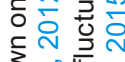

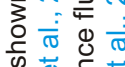

कि

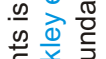

要

응

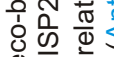

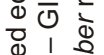

N

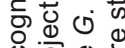

要

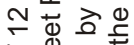

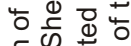

응 동용

过

के

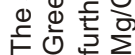


is further characterized by strong turnover in abundance between the white and pink varieties of $G$. ruber. The assemblages are characterized by an increase of G. bulloides, and the significant presence of warm water species (e.g., G. sacculifer gr., O. universa, G. aequilateralis gr.), indicative of the beginning of deglaciation. This eco-biozone matches the lowermost part of biozone $\mathrm{Y} 1$ of Kennett et al. (1985).

- GOMPFE 8 (1.79-1.65 m; 15.28-13.77 ka): this interval is marked by a progressive upwards decrease in $G$. crassaformis gr., the re-occurrence of $G$. scitula, the near-disappearance of $G$. inflata, and a concomitant increase in neogloboquadrinids. In the upper part a significant peak of $G$. bulloides marks the top of this eco-biozone. This eco-biozone coincides with the middle part of the biozone $\mathrm{Y} 1$ of Kennett et al. (1985).

- GOMPFE 7 (1.65-1.53 m; 13.77-13.09 ka): the composition of this planktonic microfauna is similar to that of eco-biozone 8, but differs by the absence of $G$. bulloides and $G$. scitula, and the last occurrence of $G$. inflata. At the base of this eco-biozone, $P$. oblioquiloculata appears in the assemblages. This eco-biozone can be related with the middle part of biozone $\mathrm{Y} 1$ of Kennett et al. (1985).

- GOMPFE 6 (1.53-1.36 m; 13.09-11.70 ka): this eco-biozone shows a microfaunal composition drastically different to that of the previous zone, suggesting that it corresponds to the YD. Re-occurrences of G. scitula and $G$. bulloides define its base. In the intermediate interval, the assemblages are characterized by an increase in $G$. crassaformis, a decrease in $O$. universa and the presence of $G$. truncatulinoides and neogloboquadrinids. This eco-biozone is equivalent to the top of the biozone $Y 1$ of Kennett et al. (1985).

- GOMPFE 5 (1.36-1.26 m; 11.70-10.20 ka): high abundances of $G$. sacculifer $g r$. and neogloboquadrinids, a gradual decrease in G. ruber alba and the absence of G. scitula and G. inflata characterize eco-biozone 5, the base of which is marked by the first consistent appearance of $G$. menardii group ( bioevent $\mathrm{f7}$ of Antonarakou et al., 2015). This eco-biozone corresponds to biozone Y1A of Kennett et al. (1985).

- GOMPFE 4 (1.26-1.01 m; 10.20-6.83 ka): this eco-biozone is defined by a re-increase in G. ruber alba, $G$. sacculifer gr. and neogloboquadrinids, as well as the presence of $G$. scitula. The base is defined by the peak of G. sacculifer gr. (Poore et al., 2003) and minimum abundance of $G$. ruber alba (bioevent $f 6$ of Antonarakou et al., 2015), while the top is marked by the disappearance of $G$. crassaformis, which is indicative of the mid-Holocene Z1/Z2 boundary (Kennett et al., 1985; bioevent $f 5$ of Antonarakou et al., 2015) in the GoM. This eco-biozone coincides with biozone Z2 of Kennett et al. (1985).

- GOMPFE 3 (1.01-0.71 m; 6.83-5.16 ka): a great expansion of warm water species characterizes eco-biozone 3. The base of this interval is marked by the first consistent occurrence of $S$. dehiscens. Increasing percentages of warm water species (G. ruber alba, $G$. sacculifer gr.; bioevent $\mathrm{f} 4$ of Antonarakou et al., 2015) and a strong reduction or absence of neogloboquadrinids and G. scitula characterize this eco-biozone that represents the lower part of biozone Z1 of Kennett et al. (1985).

- GOMPFE 2 (0.71-0.36 m; 5.16-2.38 ka): this is mainly characterized by an abrupt increase in G. menardii gr., while other warm water species such as G. ruber,
G. sacculifer and O. universa are well-represented. The re-appearance of $G$. crassaformis (bioevent $\mathrm{f} 3$ of Antonarakou et al., 2015) and decreases in G. bulloides, G. sacculifer gr., and G. aequilateralis gr. are also indicative of this interval. This eco-biozone is congruent with the middle part of biozone Z1 of Kennett et al. (1985).

- GOMPFE 1 (0.36-0 m; 2.38-0.51 ka): this is present in the uppermost part of the record. It is characterized by a strong increase in $P$. oblioquiloculata, $O$. universa and G. menardii gr. Near to the top of this eco-biozone, the minimum and maximum abundances of $G$. ruber and $P$. oblioquiloculata (bioevents f1-f2 of Antonarakou et al., 2015; Poore et al., 2003) are recognized. All these concomitant bioevents together with the completely absence of $G$. bulloides and S. dehiscens represent a distinctive late Holocene feature in the GoM. This eco-biozone corresponds to the uppermost part of biozone Z1 of Kennett et al. (1985).

\section{DISCUSSION}

ECO-BIOSTRATIGRAPHIC APPROACH

The quantitative distribution of planktonic foraminifera from the LGM to the present displays a succession of microfaunal assemblages (biozones) characterizing the progressively changing surface water environment. In such marginal basins, the successive faunal zones can be indicated as ecozones, because the majority of the species are sensitive indicators of past environmental changes with amplified signals (Drinia and Antonarakou, 2003; Antonarakou et al., 2007, 2018, 2019; Drinia et al., 2007, 2008, 2016; Kontakiotis, 2012, 2016; Kontakiotis et al., 2013, 2016a, b, 2017; Fenton et al., 2016; Karakitsios et al., 2017a, b). The ecological divergence between the species (Hemleben et al., 1989; Rohling et al., 1993), even between different morphotypes of the same species (Antonarakou et al., 2015; Kontakiotis et al., 2017), determined by different controlling factors (e.g., depth habitats, growth optimum/stressed conditions, productivity, stratification, near-/offshore-conditions), in combination with their different test morphologies (e.g., related to shell shape and size, thickness, inner porosity and pore surface distribution; Morard et al., 2009; Kontakiotis et al., 2017), control directly their distribution pattern and reflect the regional climate variability (Marcott et al., 2013). Therefore, this study uses the concept of "assemblage eco-biozones" to refer to the ecological response of planktonic foraminifera to environmental changes, rather than evolutionary changes. In this sense planktonic foraminifera are important palaeocological and palaeoclimatological indicators and such subdivision of their record provides significant insights into the hydrological dynamics of the basin studied. Moreover, the applied eco-biostratigraphic scheme effectively reflects the global climatic oscillations during the latest Quaternary. The applicability of this approach has been tested in many sediment cores collected in various marginal basins (e.g., Aegean Sea, Ionian Sea, Adriatic Sea, Tyrrhenian Sea, Caribbean Sea). The construction of such a detailed eco-biochronostratigraphic framework through the identification of these bio-ecoevents in other more or less distant cores permits the refinement of previous Late Quaternary regional schemes (Ericson and Wollin, 1968; Ruddiman, 1971; Kennett and Huddlestun, 1972; Kennett et al., 1985; Flower and Kennett, 1990; Martin et al., 1990; Wilson, 2012), makes a precise correlation between them and facilitates palaeoclimatic and/or palaeoceanographic interpretations 
of the time interval studied. Any minor discrepancies between the present and previous studies concern the degree of synchroneity between the bio-ecozone boundaries, being due to (1) the different size fractions in planktonic foraminifera analyses adopted by the authors (>100, 125, 150 or $175 \mu \mathrm{m}),(2)$ dating uncertainties of ${ }^{14} \mathrm{C}$ ages probably due to the application of a constant sea-surface ${ }^{14} \mathrm{C}$ reservoir age correction in previous studies, especially during the late glacial-interglacial transition (e.g., Broecker et al., 1988), and to (3) an absence or a weak accuracy of ${ }^{14} \mathrm{C}$ dating performed in some cases, on mixed benthic foraminifera and on pteropods (e.g., Kennett et al., 1985; Flower and Kennett, 1990).

LATE PLEISTOCENE-HOLOCENE INTEGRATED CHRONOSTRATIGRAPHIC FRAMEWORK, PALAEOCEANOGRAPHIC EVENT STRATIGRAPHY AND PALAEOENVIRONMENTAL IMPLICATIONS

A planktonic foraminiferal eco-biostratigraphy was combined with the palaeoclimatic JPC-26 records to obtain a detailed late Pleistocene-Holocene integrated stratigraphic framework for the GoM (Fig. 4). Short-term climatic and faunal fluctuations recognized during this time span can be compared to those proposed by the INTIMATE group (Björck et al., 1998; Lowe et al., 2008; Blockley et al., 2012) in Greenland ice cores.

In the lowermost part of the succession studied, eco-biozones GOMPFE 12 and GOMPFE 11 cover the time interval between 21.1 and $19.0 \mathrm{ka}$, which chronologically corresponds to the GS-2b event of the late glacial period and includes the LGM. During this interval, the planktonic assemblages show generally low diversity and are dominated by species indicating cold and productive water conditions. The coldest interval is identified in all climatic records $\left(\delta^{18} \mathrm{O}, \mathrm{Mg} / \mathrm{Ca}-\mathrm{SST}, \mathrm{PPC}\right)$ at the top of eco-biozone GOMPFE 12, characterized by a significant decrease in the warm water species $G$. ruber rosea and by the highest abundances of $G$. inflata and $G$. crassaformis, indicative of rather cool and deep mixed layers. In this part, heavier $\delta^{18} \mathrm{O}$ values and minimum SSTs of about $19^{\circ} \mathrm{C}$ are also recorded and associated with the LGM (Antonarakou et al., 2015). Nevertheless during the LGM, GoM SSTs do not display continuously low temperature values, which is consistent with relevant climate records from the tropical and subtropical Atlantic (Bard et al., 2000; Flower et al., 2004; Schmidt et al., 2004; Weldeab et al., 2006). A noticeable event, that could partly explain this slight SST rise, is the sudden increase of $G$. ruber alba, as suggested by clear positive fluctuations (e.g., in the upper part of eco-biozone GOMPFE 11). Generally, G. ruber fluctuations have been considered good recorders of climate variability (Sprovieri et al., 2006a, 2012; Budillon et al., 2009; Antonarakou et al., 2015), with its relative abundance positively co-varying with SST (Hagen and Keigwin, 2002; Sprovieri et al., 2006b) and its abundance oscillations strongly controlled by global climate forcing (Sprovieri et al., 2006b). Despite the predominance of cold species during the glacial period, an increase $(27.8-51.2 \%)$ of G. ruber alba during the LGM is a common feature of marginal records (circum-GoM/Caribbean region, Mediterranean Sea), probably due to the fact that during the LGM SSTs do not display their lowest values (Cacho et al., 2001; Sbaffi et al., 2004; Siani et al., 2010; Kontakiotis, 2016).

Eco-biozone GOMPFE 10 corresponds to the GS-2a climatic event and includes the first step of the last deglaciation, dated in the subtropical Atlantic to between 19.0 and $12.6 \mathrm{ka}$ (Aharon, 2003, 2006; Carlson et al., 2008; Sionneau et al., 2010; Schmidt and Lynch-Stieglitz, 2011; Antonarakou et al., 2015). A slight decrease in the planktonic foraminiferal diversity characterizes the assemblage, dominated by both warm and cold water species (G. crassaformis, neogloboquadrinids,
G. bulloides, G. ruber and O. universa). Mg/Ca-based estimates show a relatively stable climate period with SSTs around $22^{\circ} \mathrm{C}$. However, in the middle part of this eco-biozone ( 17.0 ka), which has been ascribed to the Heinrich 1 event (Antonarakou et al., 2015), an intensification of cold conditions is suggested by the occurrence of the heaviest $\delta^{18} \mathrm{O}$ values in the whole record. Eco-biozone GOMPFE 9 corresponds to the upper part of GS2a. The strong negative excursion in PPC and $\mathrm{Mg} / \mathrm{Ca}$-SST records at the base of this interval may be tentatively related to the Oldest Dryas (OD) event, the age of which in the GoM is documented between 16.0 and 14.7 ka (Lea et al., 2003; Williams et al., 2010).

The GOMPFE $9 / 8$ boundary is close to the boundary between the GS-2a and Gl-1 events. In this interval, a tendency toward warmer conditions is indicated by an upwards decreasing trend of cold water species (e.g., G. crassaformis) abundances and by a relative warming trend inferred from significant $\delta^{18} \mathrm{O}$ depletion in the isotopic record and concomitant increased temperatures in the $\mathrm{Mg} / \mathrm{Ca}$-based record. Eco-biozones 8 and 7 correspond to the interstadial Bølling/Allerød (B/A) sensu Mangerud et al. (1974) and the Greenland Gl-1 episode (Lowe et al., 2008) dated to between 14.8 and $13.0 \mathrm{ka}$. This event falls within the organic-rich deposits ORZ II-III, where a strong change in sedimentation rate and in planktonic biodiversity is recorded. These features prevent the identification of high-resolution climate oscillations. The observed climatic oscillations during the $\mathrm{Gl}-1$ event show three warm/humid - Gl-1e (Bølling ) and $\mathrm{Gl}-1 \mathrm{a}, \mathrm{c}$ (Allerød) - events that were interrupted by two cold/dry - Gl-1d (Older Dryas ) and GI-1b (Intra Allerød Cold Period; IACP) events on a centennial scale. All these short-term oscillations are considered to be contemporaneous with $\mathrm{Gl}-1 \mathrm{e}$ to GI-1a of the ice-core record (Fig. 4), suggesting a climatic link between the study area and the high-latitude areas.

Overall, an important climatic warming $\left(5-7^{\circ} \mathrm{C}\right.$ based on $\mathrm{Mg} / \mathrm{Ca}-\mathrm{SST}$ in Gl-1e; Antonarakou et al., 2015) and the presence of warm and seasonally stratified water masses are inferred from the structure of the assemblages of these eco-biozones, characterized by the presence of G. truncatulinoides and neogloboquadrinids. The $\delta^{18} \mathrm{O}$ record, on the whole, shows a tendency to lighter values, suggesting a climatic amelioration. However, the upwards deglaciation trend is often interrupted by brief cooling events, expressed by positive isotope excursions and/or SST negative peaks. Such an abrupt $\mathrm{Mg} / \mathrm{Ca}-\mathrm{SST}$ cold spell $\left(\sim 3^{\circ} \mathrm{C}\right)$, concomitant with a slight decrease in PPC and $\delta^{18} \mathrm{O}$ records, characterizes the uppermost part of eco-biozone 8 , attributed to the stadial GI-1d event dated in our record to $\sim 13.8 \mathrm{ka}$. A decrease in $\mathrm{G}$. ruber and O. universa accompanied by an increase of neogloboquadrinids defines the planktonic foraminiferal assemblage. A noticeable event is the temporary absence of $G$. scitula in this time interval, which records the zonal boundary between $\mathrm{Gl}-1 \mathrm{~d}$ and GI-1c (Minisini et al., 2007; Rouis-Zargouni et al., 2010; Siani et al., 2010).

The following eco-biozone GOMPFE 7 covers the time interval between 13.7 and $13.0 \mathrm{ka}$ and is attributed to the interstadial $\mathrm{Gl}-1 \mathrm{c}$ event as indicated by SST reconstruction. This interpretation fits well with the planktonic foraminiferal content, characterized by a progressive increase in warm water taxa (G. ruber, G. sacculifer gr., O. universa). The beginning of this event is punctuated by the re-occurrence of $O$. universa indicating in combination with $G$. ruber the establishment of a seasonal thermocline (Tedesco and Thunell, 2003; Tedesco et al., 2007; Wejnert et al., 2010). The $\delta^{18} \mathrm{O}$ signal indicates a strong depletion at the base ( $\mathrm{Gl}-1 \mathrm{c})$, and a weak upwards enrichment trend to cooler sea surface water conditions, which is attributed to the IACP/GI-1b event (Alley et al., 1993). Finally, at 
the top of this interval, a significant warming of about $3.5^{\circ} \mathrm{C}$ (GI-1a) is marked in the $\mathrm{Mg} / \mathrm{Ca}-\mathrm{SST}$ record. However, this event is not recorded in the PPC and $\delta^{18} \mathrm{O}$ records, most likely due to the lower resolution of the sedimentary record and/or bioturbation effects in this part of the succession.

Following this warm interval, both $\mathrm{Mg} / \mathrm{Ca}$ and $\delta^{18} \mathrm{O}$ records show a cooling trend of $3.5^{\circ} \mathrm{C}$ centered on $12.9-12.7 \mathrm{ka}$, probably representing the strong climatic cooling linked to the GS-1 event in the Greenland ice core records and the GS-1 period, dated in core JPC-26 between 13.0 and $12.5 \mathrm{ka}$. The features of the assemblages (significant increase in cold water eutrophic species associated with a decrease in warm water taxa) indicate a glacial period of generally high surface water fertility that characterizes this eco-biozone (GOMPFE 6).

The Holocene section of the record corresponds to eco-biozones GOMPFE $1-5$, and is marked by higher diversity in planktonic assemblages compared to the previous ecobiozones, and a relatively warm interval [negative $\delta^{18} \mathrm{O}$ values, elevated $\mathrm{Mg} / \mathrm{Ca}$ and PPC values; $(-0.71)-(-3.42 \%), \sim 24-30^{\circ} \mathrm{C}$ and $>70 \%$ respectively], but with pronounced warm-cold oscillations with well-defined minima (e.g., at 6.1, 5.6, and $1.1 \mathrm{ka}$ ). The latest Holocene delimits eco-biozone 5, which spans a short time interval (11.7-10.2 ka) in the JPC-26 record. SSTs reached Holocene values with a mean amplitude change observed during the $\mathrm{YD} /$ Holocene transition of about $2^{\circ} \mathrm{C}$. However, the climatic amelioration is more evident in the following eco-biozone (GOMPFE 4), corresponding to the $\mathrm{HCO}$ interval, where lighter $\delta^{18} \mathrm{O}$ and higher PPC values are recorded. The latter also includes eco-biozone GOMPFE 3, and is the result of a substantial increase in warm water taxa (G. ruber, O. universa, G. sacculifer gr., and $G$. aequilateralis gr.) and the progressive reduction (into GOMPFE 4) or absence (into GOMPFE 3) of G. crassaformis and $G$. scitula. The occurrence of a short cooling event in the lower part of eco-biozone 3 ( $6.1 \mathrm{ka})$ is suggested by significant $\delta^{18} \mathrm{O}$ depletion and reduction in the Globigerinoides ruber percentages, coupled with an increase in abundances of Globorotalia truncatulinoides as well as the re-occurrence of Globigerina bulloides. All these features in the planktonic assemblages represent an episode of improved ventilation in this basin attesting to deep winter convection and vertical mixing in the water column (Schmuker and Schiebel, 2002; Arellano-Torres and Machain-Castillo, 2017). This may correlate with the global-scale rapid climate change (RCC) at 6.0-5.0 ka BP reported in the Middle Holocene by Mayewski et al. (2004). A subsequent SST rise between 5.1-2.4 ka delineates ecobiozone GOMPFE 2. The PPC signal is close enough to its maximum values, and the species G. ruber, G. sacculifer, G. menardii gr. and neogloboquadrinids are the main constituents of the planktonic fauna. The near-absence of $G$. crassaformis, $G$. inflata and $G$. scitula may indicate that reduced oxygenation in the deeper water column was detrimental to that species, suggesting stable stratification and poor deep-water ventilation in the GoM. Within this interval and progressively through the following eco-biozone, the $\delta^{18} \mathrm{O}$ record shows the onset upwards of strong enrichment and depletion phases corresponding to a long period of marked seasonality throughout the late Holocene, possibly associated with relative changes in Mississippi River runoff. Finally, eco-biozone GOMPFE 1 presents the typical modern foraminiferal association, dominated by temperate and subtropical taxa (Dowsett et al., 2003; Richey et al., 2007; Poore et al., 2013; Arellano-Torres and Machain-Castillo, 2017).

\section{CONCLUSIONS}

The multidisciplinary approach used here results in a detailed chronostratigraphic framework for the last $21 \mathrm{ka}$ for the GoM (also valid for the peri-Caribbean region), based on the study of associations of planktonic foraminifera from the deep-sea and the high sedimentation rate core JPC-26. Twelve eco-biozones (GOMPFE 1-12) were identified by sharp changes in planktonic foraminiferal taxa and compared to the stratigraphic event scheme proposed by the INTIMATE group in order to better identify the relationships between past climatic changes and the response of microfaunal assemblages in the subtropical Atlantic. Most of these downcore faunal variations in relation to SST oscillations represent millennial to centennial climatic variability, which are recorded in Greenland ice cores over the last deglaciation. Among them, we recognized the glacial GS-2a to GS-2b events, the interstadial B-A/GI-1a-d events, the YD/GS-1 and the Holocene warm interval. Moreover, the recognition of a stratigraphic relationship between planktonic foraminiferal bioevents and organic-rich sediments enhances the possibility for reliably correlating marine records in such marginal settings, offering a better comprehension of the palaeoceanographic history of these basins. These findings represent a refinement and extension of previous eco-biostratigraphic records in the subtropical Atlantic, facilitating regional and widespread climatic and microfaunal correlations over the last $21 \mathrm{ky}$. A conclusive correlation of this work with others well known from close or more distal areas indicated the robustness of these results, with particular emphasis on multi-disciplinary strategies and multiproxy studies performed on late Quaternary cores with high sedimentation rates, which can provide a powerful tool for monitoring the palaeoclimatic evolution of the subtropical Atlantic in relation to the global climatic system over the last glacial cycle.

Acknowledgements. Constructive comments by two anonymous reviewers were critical to improving this manuscript, and Dr. W. Granoszewski (Co-Editor) is also thanked for his editorial handling.

\section{REFERENCES}

Aharon, P., 2003. Meltwater flooding events in the Gulf of Mexico revisited: implications for rapid climate changes during the las deglaciation. Paleoceanography, 18: 1079 doi:10.1029/2002PA 000840

Aharon, P., 2006. Entrainment of meltwaters in hyperpycnal flows during deglaciation superfloods in the Gulf of Mexico. Earth and Planetary Science Letters, 241: 260-270.
Alley, R.B., Meese, D.A., Shuman, C.A., Gow, A.J., Taylor, K.C., Grootes, P.M., White, J.W.C., Ram, M., Waddington, E.D., Mayewski, P.A., Zielinski, G.A., 1993. Abrupt increase in Greenland snow accumulation at the end of the Younger Dryas event. Nature, 362: 527.

Antonarakou, A., Drinia, H., Tsaparas, N., Dermitzakis, M.D., 2007. Micropaleontological parameters as proxies of Late Mio- 
cene surface water properties and paleoclimate in Gavdos Island, Eastern Mediterranean. Geodiversitas, 29: 379-399.

Antonarakou, A., Kontakiotis, G., Mortyn, P.G., Drinia, H., Sprovieri, M., Besiou, E., Tripsanas, E., 2015. Biotic and geochemical $\left(\delta^{18} \mathrm{O}, \quad \delta^{13} \mathrm{C}, \mathrm{Mg} / \mathrm{Ca}, \mathrm{Ba} / \mathrm{Ca}\right)$ responses of Globigerinoides ruber morphotypes to upper water column variations during the last deglaciation, Gulf of Mexico. Geochimica et Cosmochimica Acta, 170: 69-93.

Antonarakou, A., Kontakiotis, G., Zarkogiannis, S., Mortyn, P.G., Drinia, H., Koskeridou, E., Anastasakis, G., 2018 Planktonic foraminiferal abnormalities in coastal and open marine eastern Mediterranean environments: a natural stress monitoring approach in recent and early Holocene marine systems. Journal of Marine Systems, 181: 63-78.

Antonarakou, A., Kontakiotis, G., Vasilatos, C., Besiou, E., Zarkogiannis, S., Drinia, H., Mortyn, P.G., Tsaparas, N., Makri, P., Karakitsios, V., 2019. Evaluating the effect of marine diagenesis on Late Miocene pre-evaporitic sedimentary successions of eastern Mediterranean Sea. IOP Conference Series: Earth and Environmental Sciences, 221: 012051 doi: 10.1088/1755-1315/221/1/012051.

Antonov, J.I., Seidov, D., Boyer, T.P., Locarnini, R.A., Mishonov, A.V., Garcia, H.E., Baranova, O.K., Zweng, M.M., Johnson, D.R., 2010. World Ocean Atlas 2009, Volume 2: Salinity. In: NOAA Atlas NESDIS 69 (ed. S. Levitus). Washington, D.C., U.S. Gov. Printing Office.

Arellano-Torres, E., Machain-Castillo, M.L., 2017. Late Pleistocene-Holocene variability in the southern Gulf of Mexico surface waters based on planktonic foraminiferal assemblages. Marine Micropaleontology, 131: 44-58.

Auladell, M., Pelegrí, J.L., García-Olivares, A., Kirwan, A.D. Lipphardt, B.L., Martín, J.M., Pascual, A., Sangrà, P., Zweng, M., 2010. Modelling the early evolution of a Loop Current ring. Journal of Marine Systems, 80: 160-171

Bard, E., Rostek, F., Turon, J.-L., Gendreau, S., 2000. Hydrological Impact of Heinrich Events in the Subtropical Northeast Atlantic. Science, 289: 1321-1324.

Behringer, D.W., Molinari, R.L., Festa, J.F., 1977. The variability of anticyclonic current patterns in the Gulf of Mexico. Journal of Geophysical Research, 82: 5469-5476.

Biggs, D.C., Müller-Karger, F.E., 1994. Ship and satellite observations of chlorophyll stocks in interacting cyclone-anticyclone eddy pairs in the western Gulf of Mexico. Journal of Geophysical Research: Oceans, 99: 7371-7384.

Björck, S., Walker, M.J.C., Cwynar, L.C., Johnsen, S., Karen-Luise, K., Lowe, J.J., Wohlfarth, B., 1998. An event stratigraphy for the Last Termination in the North Atlantic region based on the Greenland ice-core record: a proposal by the INTIMATE group. Journal of Quaternary Science, 13: 283-292.

Blockley, S.P.E., Lane, C.S., Hardiman, M., Rasmussen, S.O., Seierstad, I.K., Steffensen, J.P., Svensson, A., Lotter, A.F., Turney, C.S.M., Bronk Ramsey, C., 2012. Synchronisation of palaeoenvironmental records over the last 60,000 years, and an extended INTIMATE event stratigraphy to 48,000 b2k. Quaternary Science Reviews, 36: 2-10.

Blumberg, A.F., Mellor, G.L., 1985. A simulation of the circulation in the Gulf of Mexico. Israel Journal of Earth Sciences, 34: 122-144.

Bonfardeci, A., Caruso, A., Bartolini, A., Bassinot, F., Blanc-Valleron, M.-M., 2018. Distribution and ecology of the Globigerinoides ruber-Globigerinoides elongatus morphotypes in the Azores region during the late Pleistocene-Holocene. Palaeogeography, Palaeoclimatology, Palaeoecology, 491: 92-111.

Bouma, A.H., Stelting, C.E., Coleman, J.M., 1985. Mississippi Fan, Gulf of Mexico. In: Submarine Fans and Related Turbidite Systems(eds. A.H. Bouma, W.R. Normark and N.E. Barnes): 143-150. Springer New York, New York.

Broecker, W.S., 1991. The great ocean conveyor. Oceanography, 4: 79-89.

Broecker, W.S., Andree, M., Bonani, G., Wolfli, W., Klas, M., Mix, A., Oeschger, H., 1988. Comparison between radiocarbon ages obtained on coexisting planktonic foraminifera. Paleoceanography, 3: 647-657.

Budillon, F., Lirer, F., lorio, M., Macrì, P., Sagnotti, L., Vallefuoco, M., Ferraro, L., Garziglia, S., Innangi, S., Sahabi, M., Tonielli, R., 2009. Integrated stratigraphic reconstruction for the last 80 kyr in a deep sector of the Sardinia Channel (Western Mediterranean). Deep Sea Research Part II: Topical Studies in Oceanography, 56: 725-737.

Cacho, I., Grimalt, J.O., Canals, M., Sbaffi, L., Shackleton, N.J., Schönfeld, J., Zahn, R., 2001. Variability of the western Mediterranean Sea surface temperature during the last 25,000 years and its connection with the Northern Hemisphere climatic changes. Paleoceanography, 16: 40-52.

Capotondi, L., Maria Borsetti, A., Morigi, C., 1999. Foraminiferal ecozones, a high resolution proxy for the late Quaternary biochronology in the central Mediterranean Sea. Marine Geology, 153: 253-274.

Carlson, A.E., Oppo, D.W., Came, R.E., LeGrande, A.N., Keigwin, L.D., Curry, W.B., 2008. Subtropical Atlantic salinity variability and Atlantic meridional circulation during the last deglaciation. Geology, 36: 991-994.

Caromel, A.G.M., Schmidt, D.N., Phillips, J.C., Rayfield, E.J., 2014. Hydrodynamic constraints on the evolution and ecology of planktic foraminifera. Marine Micropaleontology, 106: 69-78.

Chen, S., Hu, C., 2017. Estimating sea surface salinity in the northern Gulf of Mexico from satellite ocean color measurements. Remote Sensing of Environment, 201: 115-132.

Corbett, D.R., McKee, B., Duncan, D., 2004. An evaluation of mobile mud dynamics in the Mississippi River deltaic region. Marine Geology, 209: 91-112.

Del Monte-Luna, P., Villalobos, H., Arreguín-Sánchez, F., 2015. Variability of sea surface temperature in the southwestern Gulf of Mexico. Continental Shelf Research, 102(C): 73-79.

Dowsett, H.J., Verardo, S., Poore, R.Z., 2003. Gulf of Mexico planktonic foraminifer transfer function GOM2: preliminary report. U.S. Geological Survey Open-File Report OF 03-61.

Drinia, H., Antonarakou, A., 2003. Late Miocene paleoclimatic variations in the Eastern Mediterranean: an ecostratigraphical approach. Neues Jahrbuch für geologie und Paläontologie, 10: 603-616.

Drinia, H., Antonarakou, A., Tsaparas, N., Kontakiotis, G., 2007. Palaeoenvironmental conditions preceding the Messinian Salinity Crisis: A case study from Gavdos Island. Geobios, 40: 251-265.

Drinia, H., Antonarakou, A., Kontakiotis, G., 2008. On the occurrence of Early Pliocene marine deposits in lerapetra basin, $\mathrm{E}$. Crete. Bulletin of Geosciences, 83: 63-78.

Drinia, H., Antonarakou, A., Tsourou, T., Kontakiotis, G., Psychogiou, M., Anastasakis, G., 2016. Foraminifera eco-biostratigraphy of the southern Evoikos outer shelf, central Aegean Sea, during MIS 5 to present. Continental Shelf Research, 126: 36-49.

Elliott, B.A., 1982. Anticyclonic Rings in the Gulf of Mexico. Journal of Physical Oceanography, 12: 1292-1309.

Ericson, D.B., Wollin, G., 1968. Pleistocene Climates and Chronology in Deep-Sea Sediments. Science, 162: 1227-1234.

Fenton, I.S., Pearson, P.N., Dunkley Jones, T., Purvis, A., 2016 Environmental Predictors of Diversity in Recent Planktonic Foraminifera as Recorded in Marine Sediments. PLOS ONE, 11: e0165522.

Flower, B.P., Kennett, J.P., 1990. The Younger Dryas Cool Episode in the Gulf of Mexico. Paleoceanography, 5: 949-961.

Flower, B.P., Kennett, J.P., 1995. Biotic responses to temperature and salinity changes during the last deglaciation, Gulf of Mexico. In: Commission on Geosciences, Effects of Past Global Changes on Life: 209-220. National Academy Press, Washington, D.C.

Flower, B.P., Hastings, D.W., Hill, H.W., Quinn, T.M., 2004. Phasing of deglacial warming and Laurentide Ice Sheet meltwater in the Gulf of Mexico. Geology, 32: 597-600.

Gopalakrishnan, G., Cornuelle, B.D., Hoteit, I., Rudnick, D.L., Owens, W.B., 2013. State estimates and forecasts of the loop 
current in the Gulf of Mexico using the MITgcm and its adjoint Journal of Geophysical Research: Oceans, 118: 3292-3314.

Hagen, S., Keigwin, L.D., 2002. Sea-surface temperature variability and deep water reorganisation in the subtropical North Atlantic during Isotope Stage 2-4. Marine Geology, 189: 145-162.

Hemleben, C., Spindler, M., Anderson, O.R., 1989. Modern Planktonic Foraminifera. Springer, New York.

Hofmann, E.E., Worley, S.J., 1986. An investigation of the circulation of the Gulf of Mexico. Journal of Geophysical Research: Oceans, 91: 14221-14236.

INEGI, 2014. Anuario Estadístico y Geográfico por Entidad Federativa (in Spain). Instituto Nacional de Estadística y Geografía, Mexico.

Jochens, A.E., DiMarco, S.F., 2008. Physical oceanographic conditions in the deepwater Gulf of Mexico in summer 2000-2002. Deep Sea Research Part II: Topical Studies in Oceanography, 55: 2541-2554.

Jonkers, L., Reynolds, E., Richey, J., Hall, I.R., 2015. Lunar periodicity in the shell flux of planktonic foraminifera in the Gulf of Mexico. Biogeosciences, 12: 3061-3070.

Karakitsios, V., Roveri, M., Lugli, S., Manzi, V., Gennari, G., Antonarakou, A., Triantaphyllou, M., Agiadi, K., Kontakiotis, G., Kafousia, N., de Rafelis, M., 2017a. A record of the Messinian salinity crisis in the eastern Ionian tectonically active domain (Greece, eastern Mediterranean). Basin Research, 29: 203-233.

Karakitsios, V., Cornée, J.-J., Tsourou, T., Moissette, P., Kontakiotis, G., Agiadi, K., Manoutsoglou, E., Triantaphyllou, M. Koskeridou, E., Drinia, H., Roussos, D., 2017b. Messinian salinity crisis record under strong freshwater input in marginal, intermediate, and deep environments: the case of the North Aegean. Palaeogeography Palaeoclimatology Palaeoecology, 485: 316-335.

Kennett, J.P., Huddlestun, P., 1972. Late Pleistocene paleoclimatology, foraminiferal biostratigraphy and tephrochronology, western Gulf of Mexico. Quaternary Research, 2: 38-69.

Kennett, J.P., Srinivasan, M.S., 1983. Neogene Planktonic Foraminifera: a Phylogenetic Atlas. Hutchinson Ross Publishing Company, New York.

Kennett, J.P., Elmstrom, K., Penrose, N., 1985. The last deglaciation in orca basin, gulf of Mexico: high-resolution planktonic foraminiferal changes. Palaeogeography, Palaeoclimatology, Palaeoecology, 50: 189-216.

Kontakiotis, G., 2012. Palaeoceanographic and palaeoclimatic study of Eastern Mediterranean during Late Quaternary, based on planktonic foraminiferal assemblages (in Greek with English extended abstract). National and Kapodistrian University of Athens, Athens, Greece.

Kontakiotis, G., 2016. Late Quaternary paleoenvironmental reconstruction and paleoclimatic implications of the Aegean Sea (eastern Mediterranean) based on paleoceanographic indexes and stable isotopes. Quaternary International, 401: 28-42.

Kontakiotis, G., Mortyn, P.G., Antonarakou, A., Martínez-Botí, M.À., Triantaphyllou, M.V., 2011. Field-based validation of a diagenetic effect on $\mathrm{G}$. ruber Mg/Ca paleothermometry: core top results from the Aegean Sea (eastern Mediterranean). Geochemistry Geophysics Geosystems, 12: Q09004 doi: 10.1029/2011GC003692

Kontakiotis, G., Antonarakou, A., Zachariasse, W.J., 2013. Late Quaternary palaeoenvironmental changes in the Aegean Sea: interrelations and interactions between north and south Aegean Sea. Bulletin of the Geological Society of Greece, 47: 167-177.

Kontakiotis, G., Karakitsios, V., Mortyn, P.G., Antonarakou, A., Drinia, H., Anastasakis, G., Agiadi, K., Kafousia, N., De Rafelis, M., 2016a. New insights into the early Pliocene hydrographic dynamics and their relationship to the climatic evolution of the Mediterranean Sea. Palaeogeography, Palaeoclimatology, Palaeoecology, 459: 348-364

Kontakiotis, G., Mortyn, P.G., Antonarakou, A., Drinia, H., 2016b Assessing the reliability of foraminiferal $\mathrm{Mg} / \mathrm{Ca}$ thermometry by comparing field-samples and culture experiments: a review. Geological Quarterly, 60 (3): 547-560.
Kontakiotis, G., Antonarakou, A., Mortyn, P.G., Drinia, H., Anastasakis, G., Zarkogiannis, S., Möbius, J., 2017. Morphological recognition of Globigerinoides ruber morphotypes and their susceptibility to diagenetic alteration in the eastern Mediterranean Sea. Journal of Marine Systems, 174: 12-24.

Koutrouli, A., Anastasakis, G., Kontakiotis, G., Ballengee, S. Kuehn, S., Pe-Piper, G., Piper, D.J.W., 2018. The early to mid-Holocene marine tephrostratigraphic record in the NisyrosYali-Kos volcanic center, SE Aegean Sea. Journal of Volcanology and Geothermal Research, 366: 96-111.

Lea, D.W., Pak, D.K., Peterson, L.C., Hughen, K.A., 2003. Synchroneity of Tropical and High-Latitude Atlantic Temperatures over the Last Glacial Termination. Science, 301: 1361-1364.

Leventer, A., Williams, D.F., Kennett, J.P., 1983. Relationships between anoxia, glacial meltwater and microfossil preservation in the Orca Basin, Gulf of Mexico. Marine Geology, 53: 23-40.

Limoges, A., de Vernal, A., Van Nieuwenhove, N., 2014 Long-term hydrological changes in the northeastern Gulf of Mexico (ODP-625B) during the Holocene and late Pleistocene inferred from organic-walled dinoflagellate cysts. Palaeogeography, Palaeoclimatology, Palaeoecology, 414: 178-191.

Liu, Y., Lee, S.-K., Muhling, B.A., Lamkin, J.T., Enfield, D.B., 2012. Significant reduction of the Loop Current in the 21 st century and its impact on the Gulf of Mexico, Journal of Geophysical Research, 117, C05039-8, doi: 10.1029/2011JC007555

Locarnini, R.A., Mishonov, A.V., Antonov, J.I., Boyer, T.P., Garcia, H.E., Baranova, O.K., Zweng, M.M., Johnson, D.R., 2010. World Ocean Atlas 2009, Volume 1: Temperature. In: NOAA Atlas NESDIS 68 (ed. S. Levitus). U.S. Government Printing Office, Washington, D.C.

LoDico, J.M., Flower, B.P., Quinn, T.M., 2006. Subcentennial-scale climatic and hydrologic variability in the Gulf of Mexico during the early Holocene. Paleoceanography, 21: PA3015, doi: 10.1029/2005PA001243

Lowe, J.J., Rasmussen, S.O., Björck, S., Hoek, W.Z., Steffensen, J.P., Walker, M.J.C., Yu, Z.C., 2008 Synchronisation of palaeoenvironmental events in the North Atlantic region during the Last Termination: a revised protocol recommended by the INTIMATE group. Quaternary Science Reviews, 27: 6-17.

Luo, H., Bracco, A., Cardona, Y., McWilliams, J.C., 2016 Submesoscale circulation in the northern Gulf of Mexico: Surface processes and the impact of the freshwater river input. Ocean Modelling, 101: 68-82.

Mangerud, J.A.N., Andersen, S.T., Berglund, B.E., Donner, J.J., 1974. Quaternary stratigraphy of Norden, a proposal for terminology and classification. Boreas, 3: 109-126.

Marcott, S.A., Shakun, J.D., Clark, P.U., Mix, A.C., 2013. A Reconstruction of Regional and Global Temperature for the Past 11,300 Years. Science, 339(6124): 1198-1201.

Marino, G., Rohling, E.J., Sangiorgi, F., Hayes, A., Casford, J.L., Lotter, A.F., Kučera, M., Brinkhuis, H., 2009. Early and middle Holocene in the Aegean Sea: interplay between high and low latitude climate variability. Quaternary Science Reviews, 28: 3246-3262.

Martin, R.E., Johnson, G.W., Neff, E.D., Krantz, D.W., 1990. Quaternary planktonic foraminiferal assemblage zones of the northeast Gulf of Mexico, Colombia Basin (Caribbean Sea), and tropical Atlantic Ocean: Graphic correlation of microfossil and oxygen isotope datums. Paleoceanography, 5: 531-555.

Mayewski, P.A., Rohling, E.E., Curt Stager, J., Karlén, W. Maasch, K.A., David Meeker, L., Meyerson, E.A., Gasse, F., van Kreveld, S., Holmgren, K., Lee-Thorp, J., Rosqvist, G., Rack, F., Staubwasser, M., Schneider, R.R., Steig, E.J., 2004. Holocene climate variability. Quaternary Research, 62: 243-255.

Meckler, A.N., Schubert, C.J., Hochuli, P.A., Plessen, B., Birgel, D., Flower, B.P., Hinrichs, K.U., Haug, G.H., 2008. Glacial to Holocene terrigenous organic matter input to sediments from Orca Basin, Gulf of Mexico - a combined optical and biomarker approach. Earth and Planetary Science Letters, 272: 251-263. 
Metcalfe, S.E., O'Hara, S.L., Caballero, M., Davies, S.J., 2000 Records of Late Pleistocene-Holocene climatic change in Mexico - a review. Quaternary Science Reviews, 19: 699-721.

Minisini, D., Trincardi, F., Asioli, A., Canu, M., Foglini, F., 2007 Morphologic variability of exposed mass-transport deposits on the eastern slope of Gela Basin (Sicily channel). Basin Research, 19: 217-240.

Montero-Serrano, J.C., Bout-Roumazeilles, V., Tribovillard, N., Sionneau, T., Riboulleau, A., Bory, A., Flower, B., 2009. Sedimentary evidence of deglacial megafloods in the northern Gulf of Mexico (Pigmy Basin). Quaternary Science Reviews, 28: 3333-3347.

Montero-Serrano, J.C., Bout-Roumazeilles, V., Sionneau, T., Tribovillard, N., Bory, A., Flower, B.P., Riboulleau, A., Martinez, P., Billy, I., 2010. Changes in precipitation regimes over North America during the Holocene as recorded by mineralogy and geochemistry of Gulf of Mexico sediments. Global and Planetary Change, 74: 132-143.

Montero-Serrano, J.C., Bout-Roumazeilles, V., Carlson Anders, E., Tribovillard, N., Bory, A., Meunier, G., Sionneau, T., Flower Benjamin, P., Martinez, P., Billy, I., Riboulleau, A., 2011. Contrasting rainfall patterns over North America during the Holocene and Last Interglacial as recorded by sediments of the northern Gulf of Mexico. Geophysical Research Letters, 38, L14709, doi: 10.1029/2011GL048194

Morard, R., Quillévéré, F., Escarguel, G., Ujiie, Y., de GaridelThoron, T., Norris, R.D., de Vargas, C., 2009. Morphological recognition of cryptic species in the planktonic foraminifer Orbulina universa. Marine Micropaleontology, 71: 148-165.

Morey, S.L., Martin, P.J., O'Brien, J.J., Wallcraft, A.A., Zavala-Hidalgo, J., 2003a. Export pathways for river discharged fresh water in the northern Gulf of Mexico. Journal of Geophysical Research: Oceans, 108 (C10), 3303, doi: 10.1029/2002JC001674

Morey S.L., Schroeder William, W., O'Brien James, J., Zavala-Hidalgo, J., 2003b. The annual cycle of riverine influence in the eastern Gulf of Mexico basin. Geophysical Research Letters, 30 (16), 1867, doi: 10.1029/2003GL017348

Müller-Karger, F.E., Walsh, J.J., Evans, R.H., Meyers, M.B., 1991. On the seasonal phytoplankton concentration and sea surface temperature cycles of the Gulf of Mexico as determined by satellites. Journal of Geophysical Research: Oceans, 96 : 12645-12665.

Nürnberg, D., Ziegler, M., Karas, C., Tiedemann, R., Schmidt, M.W., 2008. Interacting Loop Current variability and Mississippi River discharge over the past 400 kyr. Earth and Planetary Science Letters, 272: 278-289.

Oey, L., Ezer, T., Lee, H., 2013. Loop Current, rings and related circulation in the Gulf of Mexico: a review of numerical models and future challenges, circulation in the Gulf of Mexico: observations and models. Geophysical Monograph Series, 161: 31-56.

OhImann, J.C., Niiler, P.P., Fox, C.A., Leben, R.R., 2001. Eddy energy and shelf interactions in the Gulf of Mexico. Journal of Geophysical Research: Oceans, 106: 2605-2620.

Patterson, R.T., Fishbein, E., 1989. Re-examination of the statistical methods used to determine the number of point counts needed for micropaleontological quantitative research. Journal of Paleontology, 63: 245-248.

Poore, R.Z., Dowsett, H.J., Verardo, S., Quinn, T.M., 2003. Millennial- to century-scale variability in Gulf of Mexico Holocene climate records. Paleoceanography, 18, 1048, doi: 10.1029/2002PA000868

Poore, R.Z., Quinn, T.M., Verardo, S., 2004. Century-scale movement of the Atlantic Intertropical Convergence Zone linked to solar variability. Geophysical Research Letters, 31, L12214, doi: 10.1029/2004GL019940

Poore, R.Z., Pavich, M.J., Grissino-Mayer, H.D., 2005. Record of the North American southwest monsoon from Gulf of Mexico sediment cores. Geology, 33: 209-212.

Poore, R.Z., Tedesco, K.A., Spear, J.W., 2013. Seasonal flux and Assemblage composition of planktic foraminifers from a sediment-trap study in the Northern Gulf of Mexico. Journal of Coastal Research: 6-19.
Putrasahan, D.A., Kamenkovich, I., Le Hénaff, M., Kirtman, B.P., 2017. Importance of ocean mesoscale variability for air-sea interactions in the Gulf of Mexico. Geophysical Research Letters, 44: 6352-6362.

Rasmussen, T.L., Thomsen, E., 2012. Changes in planktic foraminiferal faunas, temperature and salinity in the Gulf Stream during the last 30,000 years: influence of meltwater via the Mississippi River. Quaternary Science Reviews, 33: 42-54.

Renaud, S., Schmidt, D.N., 2003. Habitat tracking as a response of the planktic foraminifer Globorotalia truncatulinoides to environmental fluctuations during the last $140 \mathrm{kyr}$. Marine Micropaleontology, 49: 97-122.

Reynolds, C.E., Richey, J.N., Fehrenbacher, J.S., Rosenheim, B.E., Spero, H.J., 2018. Environmental controls on the geochemistry of Globorotalia truncatulinoides in the Gulf of Mexico: implications for paleoceanographic reconstructions. Marine Micropaleontology, 142: 92-104.

Richey, J.N., Poore, R.Z., Flower, B.P., Quinn, T.M., 2007. 1400 yr multiproxy record of climate variability from the northern Gulf of Mexico. Geology, 35: 423-426.

Richey, J.N., Hollander, D.J., Flower, B.P., Eglinton, T.I., 2011 Merging late Holocene molecular organic and foraminiferal-based geochemical records of sea surface temperature in the Gulf of Mexico. Paleoceanography, 26, PA1209, doi: 10.1029/2010PA002000

Richey, J.N., Poore, R.Z., Flower, B.P., Hollander, D.J., 2012 Ecological controls on the shell geochemistry of pink and white Globigerinoides ruber in the northern Gulf of Mexico: implications for paleoceanographic reconstruction. Marine Micropaleontology, 82-83: 28-37.

Rohling, E.J., Jorissen, F.J., Grazzini, C.V., Zachariasse, W.J., 1993. Northern Levantine and Adriatic Quaternary planktic foraminifera; Reconstruction of paleoenvironmental gradients. Marine Micropaleontology, 21: 191-218.

Rouis-Zargouni, I., Turon, J.-L., Londeix, L., Essallami, L., Kallel, N., Sicre, M.-A., 2010. Environmental and climatic changes in the central Mediterranean Sea (Siculo-Tunisian Strait) during the last $30 \mathrm{ka}$ based on dinoflagellate cyst and planktonic foraminifera assemblages. Palaeogeography, Palaeoclimatology, Palaeoecology, 285: 17-29.

Ruddiman, W.F., 1971. Pleistocene Sedimentation in the Equatorial Atlantic: Stratigraphy and Faunal Paleoclimatology. GSA Bulletin, 82: 283-302.

Saha, K., 2010. Large-Scale Tropical Circulations. Springer, Berlin, Heidelberg.

Sbaffi, L., Wezel, F.C., Curzi, G., Zoppi, U., 2004. Millennial- to centennial-scale palaeoclimatic variations during Termination I and the Holocene in the central Mediterranean Sea. Global and Planetary Change, 40: 201-217.

Schmidt, D.N., Renaud, S., Bollmann, J., Schiebel, R., Thierstein, H.R., 2004a. Size distribution of Holocene planktic foraminifer assemblages: biogeography, ecology and adaptation. Marine Micropaleontology 50: 319-338.

Schmidt, D.N., Thierstein, H.R., Bollmann, J., Schiebel, R., 2004b. Abiotic forcing of plankton evolution in the Cenozoic. Science 303: 207-210.

Schmidt, M.W., Spero, H.J., Lea, D.W., 2004. Links between salinity variation in the Caribbean and North Atlantic thermohaline circulation. Nature, 428: 160-163.

Schmidt, M.W., Lynch-Stieglitz, J., 2011. Florida Straits deglacial temperature and salinity change: Implications for tropical hydrologic cycle variability during the Younger Dryas. Paleoceanography, 26, PA4205, doi: 10.1029/21011PA002157

Schmidt, M.W., Weinlein, W.A., Marcantonio, F., Lynch-Stieglitz, J., 2012. Solar forcing of Florida Straits surface salinity during the early Holocene. Paleoceanography, 27.

Schmitz, J.W.J., Biggs, D.C., Lugo-Fernandez, A., Oey, L.Y., Sturges, W., 2013. A Synopsis of the Circulation in the Gulf of Mexico and on its Continental Margins. In: Circulation in the Gulf of Mexico: Observations and Models (eds. W. Sturges and A. Lugo-Fernandez): 11-29. American Geophysical Union, Washington, D.C 
Schmuker, B., Schiebel, R., 2002. Planktic foraminifers and hydrography of the eastern and northern Caribbean Sea. Marine Micropaleontology, 46: 387-403.

Shakun, J.D., Raymo, M.E., Lea, D.W., 2016. An early Pleistocene $\mathrm{Mg} / \mathrm{Ca}-\delta^{18} \mathrm{O}$ record from the Gulf of Mexico: evaluating ice sheet size and pacing in the 41-kyr world. Paleoceanography, 31, doi: 10.1002/2016PA002956

Siani, G., Paterne, M., Colin, C., 2010. Late glacial to Holocene planktic foraminifera bioevents and climatic record in the South Adriatic Sea. Journal of Quaternary Science, 25: 808-821.

Sionneau, T., Bout-Roumazeilles, V., Biscaye, P.E., Van Vliet-Lanoe, B., Bory, A., 2008. Clay mineral distributions in and around the Mississippi River watershed and Northern Gulf of Mexico: sources and transport patterns. Quaternary Science Reviews, 27: 1740-1751.

Sionneau, T., Bout-Roumazeilles, V., Flower, B.P., Bory, A., Tribovillard, N., Kissel, C., Van Vliet-Lanoë, B., Montero Serrano, J.C., 2010. Provenance of freshwater pulses in the Gulf of Mexico during the last deglaciation. Quaternary Research, 74: 235-245.

Spear, J.W., Poore, R.Z., Quinn, T.M., 2011a. Globorotalia truncatulinoides (dextral) $\mathrm{Mg} / \mathrm{Ca}$ as a proxy for Gulf of Mexico winter mixed-layer temperature: Evidence from a sediment trap in the northern Gulf of Mexico. Marine Micropaleontology, 80: 53-61.

Spear, J.W., Reynolds, C.E., Poore, R.Z., 2011b. Seasonal Flux and Assemblage Composition of Planktic Foraminifera from the Northern Gulf of Mexico, 2008-2009. U.S. Geological Survey Open-File Report, 2011-1002.

Sprovieri, R., Di Stefano, E., Incarbona, A., Gargano, M.E., 2003 A high-resolution record of the last deglaciation in the Sicily Channel based on foraminifera and calcareous nannofossi quantitative distribution. Palaeogeography, Palaeoclimatology, Palaeoecology, 202: 119-142.

Sprovieri, R., Di Stefano, E., Incarbona, A., Oppo, D.W., 2006a Suborbital climate variability during Marine Isotopic Stage 5 in the central Mediterranean basin: evidence from calcareous plankton record. Quaternary Science Reviews, 25: 2332-2342.

Sprovieri, R., Sprovieri, M., Caruso, A., Pelosi, N., Bonomo, S., Ferraro, L., 2006b. Astronomic forcing on the planktonic foraminifera assemblage in the Piacenzian Punta Piccola section (southern Italy). Paleoceanography, 21, PA4204 doi:10.1029/2006PA001268

Sprovieri, M., Di Stefano, E., Incarbona, A., Salvagio Manta, D. Pelosi, N., Ribera d'Alcalà, M., Sprovieri, R., 2012. Centennial- to millennial-scale climate oscillations in the Central-Eastern Mediterranean Sea between 20,000 and 70,000 years ago: evidence from a high-resolution geochemical and micropaleontological record. Quaternary Science Reviews, 46: 126-135.

Tedesco, K.A., Thunell, R.C., 2003. Seasonal and interannual variations in Planktonic Foraminiferal flux and assemblage composition in the Cariaco Basin, Venezuela. Journal of Foraminiferal Research, 33: 192-210.

Tedesco, K., Thunell, R., Astor, Y., Muller-Karger, F., 2007. The oxygen isotope composition of planktonic foraminifera from the Cariaco Basin, Venezuela: seasonal and interannual variations. Marine Micropaleontology, 62: 180-193.

Thirumalai, K., Richey, J.N., Quinn, T.M., Poore, R.Z., 2014 Globigerinoides ruber morphotypes in the Gulf of Mexico: a test of null hypothesis. Scientific Reports, 4, 6018: 1-7.

Thirumalai, K., Quinn, T.M., Okumura, Y., Richey, J.N., Partin, J.W., Poore, R.Z., Moreno-Chamarro, E., 2018. Pronounced centennial-scale Atlantic Ocean climate variability correlated with Western Hemisphere hydroclimate. Nature Communications, 9: 392.

Toner, M., Kirwan, A.D., Poje, A.C., Kantha, L.H., Müller-Karger, F.E., Jones, C.K.R.T., 2003. Chlorophyll dispersal by eddy-eddy interactions in the Gulf of Mexico. Journal of Geophysical Re$\begin{array}{llll}\text { search: } & \text { Oceans, } & 108 & \text { (C4), }\end{array}$ http://dx.doi.org/10.1029/2002JC001499

Triantaphyllou, M.V., Antonarakou, A., Kouli, K., Dimiza, M., Kontakiotis, G., Papanikolaou, M.D., Ziveri, P., Mortyn, P.G., Lianou, V., Lykousis, V., Dermitzakis, M.D., 2009. Late Gla-
cial-Holocene ecostratigraphy of the south-eastern Aegean Sea, based on plankton and pollen assemblages. Geo-Marine Letters, 29: 249-267.

Tripsanas, E.K., Bryant, W.R., Slowey, N.C., Bouma, A.H., Karageorgis, A.P., Berti, D., 2007. Sedimentological history of Bryant Canyon area, northwest Gulf of Mexico, during the last $135 \mathrm{kyr}$ (Marine Isotope Stages 1-6): a proxy record of Mississippi River discharge. Palaeogeography, Palaeoclimatology, Palaeoecology, 246: 137-161.

Tripsanas, E.K., Karageorgis, A.P., Panagiotopoulos, I.P., Koutsopoulou, E., Kanellopoulos, T.D., Bryant, W.R., Slowey, N.C., 2013. Paleoenvironmental and paleoclimatic implications of enhanced Holocene discharge from the Mississippi river based on the sedimentology and geochemistry of a deep core (JPC-26) from the Gulf of Mexico. PALAIOS, 28: 623-636.

Vetter, L., Spero, H.J., Eggins, S.M., Williams, C., Flower, B.P., 2017. Oxygen isotope geochemistry of Laurentide ice-sheet meltwater across Termination I. Quaternary Science Reviews, 178: 102-117.

Wang, C., Enfield, D., B., 2001. The tropical western hemisphere warm pool. Geophysical Research Letters, 28: 1635-1638.

Wawrik, B., Paul, J.H., Campbell, L., Griffin, D., Houchin, L., Fuentes-Ortega, A., Muller-Karger, F., 2003. Vertical structure of the phytoplankton community associated with a coastal plume in the Gulf of Mexico. Marine Ecology Progress Series, 251: 87-101.

Weisberg, R.H., Liu, Y., 2017. On the Loop Current penetration into the Gulf of Mexico. Journal of Geophysical Research: Oceans, 122: 9679-9694.

Wejnert, K.E., Pride, C.J., Thunell, R.C., 2010. The oxygen isotope composition of planktonic foraminifera from the Guaymas Basin, Gulf of California: Seasonal, annual, and interspecies variability. Marine Micropaleontology, 74: 29-37.

Weldeab, S., Schneider, R.R., Kölling, M., 2006. Deglacial sea surface temperature and salinity increase in the western tropical Atlantic in synchrony with high latitude climate instabilities. Earth and Planetary Science Letters, 241: 699-706.

Williams, C., Flower Benjamin, P., Hastings David, W., Guilderson Thomas, P., Quinn Kelly, A., Goddard Ethan, A., 2010. Deglacial abrupt climate change in the Atlantic Warm Pool: a Gulf of Mexico perspective. Paleoceanography, 25, PA4221, doi: 10.1029/2010PA001928

Williams, D.F., Kohl, B., 1986. Isotope chronostratigraphy and carbonate record for quaternary site-619, Pygmy Basin, Louisiana continental-slope. Initial Reports of the Deep Sea Drilling Project: 671-676.

Wilson, B., 2012. Biogeography and ecostratigraphy of Late Quaternary planktonic foraminiferal taphocoenoses in the Leeward Islands, Lesser Antilles, NE Caribbean Sea. Marine Micropaleontology, 86-87: 1-10.

Wilson, J.D., Monteiro, F.M., Schmidt, D.N., Ward, B.A., Ridgwell, A., 2018. Linking marine plankton ecosystems and climate: A new modeling approach to the warm early Eocene climate. Paleoceanography and Paleoclimatology, 33 doi.org/10.1029/2018PA003374

Zarkogiannis, S.D., Kontakiotis, G., Antonarakou, A., Mortyn, P.M., Drinia, H., 2019a. Latitudinal variation of planktonic foraminifera shell masses during Termination I. IOP Conference Series: Earth and Environmental Sciences, 221: 012052 doi:10.1088/1755-1315/221/1/012052

Zarkogiannis, S.D., Antonarakou, A., Tripati, A., Kontakiotis, G., Mortyn, P.G., Drinia, H., Greaves, M., 2019b. Influence of surface ocean density on planktonic foraminifera calcification. Scientific Reports, 9: 533, doi: 10.1038/s41598-018-36935-7

Zavala-Hidalgo, J., Morey, S.L., O’brien, J.J., Zamudio, L., 2006. On the Loop Current eddy shedding variability. Atmósfera, 19: 41-48

Ziegler, M., Nürnberg, D., Karas, C., Tiedemann, R., Lourens, L.J., 2008. Persistent summer expansion of the Atlantic Warm Pool during glacial abrupt cold events. Nature Geoscience, 1: 601-605. 